\title{
ADSORPCJA DWUFUNKCYJNYCH LABILNYCH SURFAKTANTÓW KATIONOWYCH NA GRANICY \\ FAZ CIECZ/GAZ \\ - OPIS ZA POMOCĄ MODELU KWAZI- DWUWYMIAROWEGO ELEKTROLITU
}

\section{ADSORPTION OF DICEPHALIC LABILE CATIONIC SURFACTANTS \\ AT LIQUID/GAS INTERFACES - SURFACE QUASI- TWO-DIMENSIONAL ELECTROLYTE MODEL DESCRIPTON}

\section{Renata Frąckowiak ${ }^{1}$, Grażyna Para ${ }^{2}$, Lukasz Lamch $^{1}$, Lilianna Szyk-Warszyńska ${ }^{2}$, Kazimiera A. Wilk ${ }^{1}$, Piotr Warszyński ${ }^{2}$ *}

${ }^{1}$ Wydziat Chemiczny, Katedra Inżynierii i Technologii Procesów Chemicznych, Politechnika Wrocławska, Wybrzeże Wyspiańskiego 27, 50-370 Wrocław, Polska ${ }^{2}$ Instytut Katalizy i Fizykochemii Powierzchni im. Jerzego Habera, PAN, ul. Niezapominajek 8, 30-239 Kraków, Polska

*e-mail:ncwarszy@cyf-kr.edu.pl; kazimiera.wilk@pwr.edu.pl

\section{Abstract}

Wprowadzenie

1. Kationowe surfaktanty wielofunkcyjne

2. Właściwości użytkowe kationowych surfaktantów wielofunkcyjnych

3. Adsorpcja surfaktantów na granicy faz ciecz/gaz

4. Teoretyczne modele adsorpcji jonowych surfaktantów

5. Aktywność powierzchniowa dwufunkcyjnych surfaktantów kationowych typu soli amoniowych

6. Aktywność powierzchniowa dichlorków $N, N$-bis(3,3'-dimetyloaminopropylo) alkilamidów

Uwagi końcowe

Podziękowania

Piśmiennictwo cytowane 
Dr inż. Renata Frąckowiak w roku 2007 ukończyła studia na Wydziale Chemicznym Politechniki Wrocławskiej, a w roku 2011 obroniła z wyróżnieniem pracę doktorską pod kierunkiem prof. Kazimiery A. Wilk na Wydziale Chemicznym Politechniki Wrocławskiej, nagrodzoną w 2012 roku Nagrodą Prezesa Rady Ministrów oraz Nagrodą Rektora Politechniki Wrocławskiej. W latach 2011-2013 pracowała na stanowisku asystenta naukowo-dydaktycznego na Wydziale Chemicznym Politechniki Wrocławskiej. Badania naukowe prowadziła w obszarze chemii i technologii surfaktantów i układów dyspersyjnych. Od roku 2013 pracuje w PCC Exol S.A. w Brzegu Dolnym. W latach 2013-2016 pracowała na stanowisku specjalisty ds. rozwoju w Dziale Badań i Rozwoju, a od 2016 roku objęła stanowisko Menadżera Produktu w zakresie projektów dotyczących opracowywania i wdrażania nowych produktów i technologii do branży kosmetyków i detergentów.

Dr Grażyna Para ukończyła studia chemiczne na Wydziale Matematyki, Fizyki i Chemii Uniwersytetu Jagiellońskiego. W latach od 1973 do 2016 pracowała w Instytucie Katalizy i Fizykochemii Powierzchni PAN. Tematyka jej badań naukowych obejmowała zagadnienia szeroko pojętej fizykochemii zjawisk powierzchniowych, ze szczególnym uwzględnieniem kinetyki adsorpcji substancji powierzchniowo aktywnych na swobodnej powierzchni roztworu i na granicy faz roztwór wodny/rtęć. Znaczącym efektem tych badań była eksperymentalna weryfikacja, rozwiniętego w Instytucie modelu teoretycznego dotyczącego wpływu elektrolitów na adsorpcję surfaktantów jonowych. Wyniki tych badań przedstawiła w pracy doktorskiej wykonanej pod kierunkiem prof. Piotra Warszyńskiego w 2006 r.

Dr inż. Lukasz Lamch w roku 2013 ukończył studia na Wydziale Chemicznym Politechniki Wrocławskiej, a w roku 2018 obronił z wyróżnieniem pracę doktorską pod kierunkiem prof. Kazimiery A. Wilk na Wydziale Chemicznym Politechniki Wrocławskiej, nagrodzoną w 2019 roku Nagrodą Rektora Politechniki Wrocławskiej. Od roku 2018 jest zatrudniony na PWr na stanowisku adiunkta . W roku 2017 odbył staż technologiczny w zakładach EBS Ink-Jet Systems we Wrocławiu, a w 2021 prowadzi badania naukowe na Uniwersytecie w Szeged (Węgry) w ramach stypendium Funduszy Wyszehradzkich. Specjalność technologia i inżynieria surfaktantów oraz układów zdyspergowanych (surfaktanty specjalistyczne, amfifilowe kopolimery blokowe i ich wykorzystanie do konstruowania nanonośników dla zastosowań terapeutycznych).

(iD https://orcid.org/0000-0002-0332-7119

Dr inż. Lilianna Szyk-Warszyńska w roku 1986 ukończyła studia na Wydziale Chemicznym Politechniki Gdańskiej, a w roku 1998 obroniła pracę doktorską pod kierunkiem prof. Zbigniewa Adamczyka w Instytucie Katalizy i Fizykochemii Powierzchni im. Jerzego Habera Polskiej Akademii Nauk w Krakowie, gdzie jest zatrudniona od 1991 roku. W latach 1999-2001 odbyła staż naukowy w INSERM, Strasbourg we Francji. Jej zainteresowania naukowe koncentrują się wokół adsorpcji polielektrolitów, białek i surfaktantów na stałych powierzchniach międzyfazowych, oraz uwalnianiu związków biologicznie czynnych z wnętrza mikrokapsułek poprzez multiwarstwy polielektrolitowe. 
Prof. dr hab. inż. Kazimiera A. Wilk jest absolwentką Wydziału Chemicznego Politechniki Wrocławskiej (1976), pracę doktorską pod kierunkiem prof. Jana Chlebickiego obroniła w 1979 r., zaś stopień doktora habilitowanego nauk chemicznych - w 1991 r.. W styczniu 2001 roku uzyskała tytuł profesora. W latach 1996 -2020, jako następca Profesora Bogdana Burczyka, była kierownikiem szeregu kolejnych zakładów naukowo - dydaktycznych z zakresu technologii chemicznej organicznej na PWr. Aktualnie jest kierownikiem Laboratorium Badawczego Technologii Organicznej i Farmaceutycznej w ramach Katedry Inżynierii i Technologii Procesów Chemicznych na Wydziale Chemicznym PWr. W latach 2017-2020 była członkiem Centralnej Komisji ds. Stopni i Tytułów (Nauki Chemiczne/Technologia Chemiczna), zaś w latach 2019-2023 jest członkiem Rady Doskonałości Naukowej (Inżynieria Chemiczna). Jej zainteresowania naukowe koncentrują się wokół innowacyjnych technologii chemikaliów specjalistycznych (ang. Fine Chemicals), obejmujące surfaktanty specjalistyczne oraz amfifilowe kopolimery blokowe, racjonalne nano- i mikronośniki do spowolnionego uwalniania leków, a także racjonalne formy surfaktantowe typu kosmeceutyków.

https://orcid.org/0000-0002-2020-1761

Prof. dr hab. inż. Piotr Warszyński jest absolwentem AGH w Krakowie (1982), prace doktorska pod kierunkiem dr. hab. Jana Czarneckiego w Instytucie Chemii Fizycznej obronił w 1988 roku. W latach 19901993 pracował na McGill University w Montrealu. W roku 2000 uzyskał stopień doktora habilitowanego nauk chemicznych, a w 2008 roku, tytuł profesora. Od 1994 jest nieprzerwanie zatrudniony w Instytucie Katalizy i Fizykochemii Powierzchni im. Jerzego Habera PAN. W latach 2002-2011 pełnił funkcje Zastępcy Dyrektora Instytutu. Obecnie jest kierownikiem grupy badawczej „Nanostruktury Materii Miękkiej”. Zainteresowania naukowe koncentrują się wokół zagadnień adsorpcji surfaktantów, polimerów i nanocząstek, właściwości funkcjonalnych cienkich filmów, zagadnień stabilności układów koloidalnych i enkapsulacji substancji aktywnych. W latach 2015-2017 był Prezydentem European Colloid and Interface Science Society (ECIS).

https://orcid.org/0000-0001-5449-9060 


\begin{abstract}
There is an increasing interest in surfactants that comprise a linkage that breaks down in a controlled way. The most known examples of the cleavage mechanism include acid or alkaline hydrolysis, UV irradiation, enzymatic or heat decomposition. For practical reasons, the labile grouping can be inserted between the hydrophobic tail of the surfactant and the polar head group. Chemically and/or enzymatically induced cleavage of this labile bond would cause the separation of the polar part and the hydrophobic tail and, consequently, change of surface activity, an event usually referred to as the primary degradation of the surfactant. Dicephalic labile cationic surfactants belong to the class of surface active compounds with many potential applications often associated with their biological activity for a wide range of bacteria, viruses, fungi, or algae. Thus, they can be used in disinfecting agents or for protecting against the occurrence of these microorganisms. They adsorb well on negatively charged surfaces, which can be used in the treatment of fabrics. Due to excellent antistatic properties, they can be used for the final rinsing of fabrics, especially synthetic ones. In flotation processes, they can act as collectors, and in catalysis, they can be used as phase transfer catalysts or templates for zeolite synthesis.

We present the surface quasi-two-dimensional electrolyte (STDE) model as a universal model for the description of ionic surfactants' adsorption at fluid interfaces that explicitly considers the electric double formation upon surfactant adsorption. The model was adapted to describe phenomena occurring for adsorption of dicephalic surfactants as counterion specificity or formation of surfactant ioncounterion associates. As an example, we applied the model to explain the mechanism of adsorption at water/air interface of novel dicephalic cationic surfactants, $\quad N, N$-bis[3,3'-(trimethylammonio)propyl]alkylamide dibromides and $N, N$-bis[3,3'-(trimethylammonio)propyl]alkylamide dimethylsulfates, both belonging to the class of chemodegradable surfactants having amide bond between two quaternary amine cationic groups and a single hydrophobic tail. Additionally, we used the same model to describe adsorption isotherms of N,N-bis[3,3(dimethylamine)propyl]alkylamide dichlorides, having as two hydrophilic groups tertiary amines, which charge is pH-dependent. Application of the STDE model allowed an excellent description of experimental adsorption isotherm of dicephalic cationic surfactants and explained the specific features connected with the presence of multicharged headgroup.
\end{abstract}

Keywords: multifunctional cationic surfactants, chemodegradable surfactants, adsorption, surface tension, adsorption model

Słowa kluczowe: kationowe surfaktanty wielofunkcyjne, surfaktanty chemodegradowalne, adsorpcja, napięcie powierzchniowe, model adsorpcji 


\section{WPROWADZENIE}

Związki powierzchniowo czynne, nazywane także surfaktantami, to bardzo zróżnicowana grupa pochodnych mająca wiele zastosowań w różnych obszarach życia codziennego. Począwszy od wykorzystania w środkach czyszczących czy piorących, przez emulgatory/stabilizatory/dyspergatory kosmetyków czy żywności aż po specjalistyczne zastosowania $\mathrm{w}$ farmacji i medycynie, stanowią niezastąpione składniki wielu rozmaitych produktów. Surfaktanty, ze względu na budowę chemiczną, są związkami, które w obrębie jednej cząsteczki zawierają zarówno ugrupowanie hydrofilowe, wykazujące powinowactwo do fazy wodnej, jak i hydrofobowe (lipofilowe) - rozpuszczalne w fazie olejowej. W warunkach odpowiedniej równowagi hydrofilowo-lipofilowej (ang. hydrophilic-lipophilic balance, HLB), kiedy fragmenty związku pozostają w odpowiedniej proporcji, związki te obniżają napięcie powierzchniowe, agregują w objętości i na granicach faz. Konsekwencją specyficznej budowy surfaktantów są następujące zjawiska fizykochemiczne: aktywność powierzchniowa, adsorpcja i micelizacja, zwilżalność, pianotwórczość, emulgowanie, solubilizacja, dyspergowanie, a także antystatyzacja materiałów (głównie w przypadku struktur kationowych) [1-6].

Strategie projektowania nowych struktur surfaktantów opierają się na dążeniu do otrzymania związków o zamierzonych właściwościach fizykochemicznych i o zadanych specyficznych cechach użytkowych. Wytwarzanie nowych, najczęściej złożonych struktur surfaktantów wielofunkcyjnych (przykładowe struktury - Rys. 1), w szczególności typu „szytych na miarę” (ang. customdesigned) oraz surfaktantów specjalistycznych (ang. specialty surfactants) oraz potrzeba zrozumienia zależności pomiędzy budową a ich właściwościami, jest przedmiotem dynamicznie rozwijających się badań w zakresie nauk chemicznych, inżynierii i technologii chemicznej czy inżynierii materiałowej [1,2]. Ze względów środowiskowych wzrasta zainteresowanie produktami zawierającymi w swojej strukturze wiązanie labilne, które może pękać w kontrolowany sposób w wyniku hydrolizy kwasowej, hydrolizy zasadowej, pod wpływem promienowania UV, działania enzymów lub w wyniku rozkładu termicznego [3]. Ze względów praktycznych labilne ugrupowanie można umieścić między hydrofobową a hydrofilową częścią surfaktantu. Rozszczepienie tego wiązania, wywołane chemicznie i/lub enzymatycznie, powoduje oddzielenie części polarnej i hydrofobowej, a w konsekwencji zmianę aktywności powierzchniowej. Proces ten zwykle określany jest jako pierwotna degradacja środka powierzchniowo czynnego. Następująca po nim biodegradacja przebiega różnymi drogami w zależności od rodzaju pierwotnych produktów degradacji. Wprowadzenie po raz pierwszy do literatury światowej terminu surfaktanty chemodegradowalne (ang. chemodegrada- 
ble surfactants) dla opisu tego rodzaju związków jest niewątpliwą zasługą profesora Bogdana Burczyka [4,5].

Wśród znanych, chemodegradowalnych surfaktantów jonowych znajdują się funkcjonalizowane czwartorzędowe sole amoniowe należące do grupy surfaktantów kationowych. Analiza jakościowa oraz opis teoretyczny procesu adsorpcji kationowych surfaktantów o znaczeniu technologicznym stanowiły, w niniejszym opracowaniu, punkt wyjścia do rozważań nad korelacją pomiędzy strukturą molekularną badanych związków a ich właściwościami powierzchniowymi.

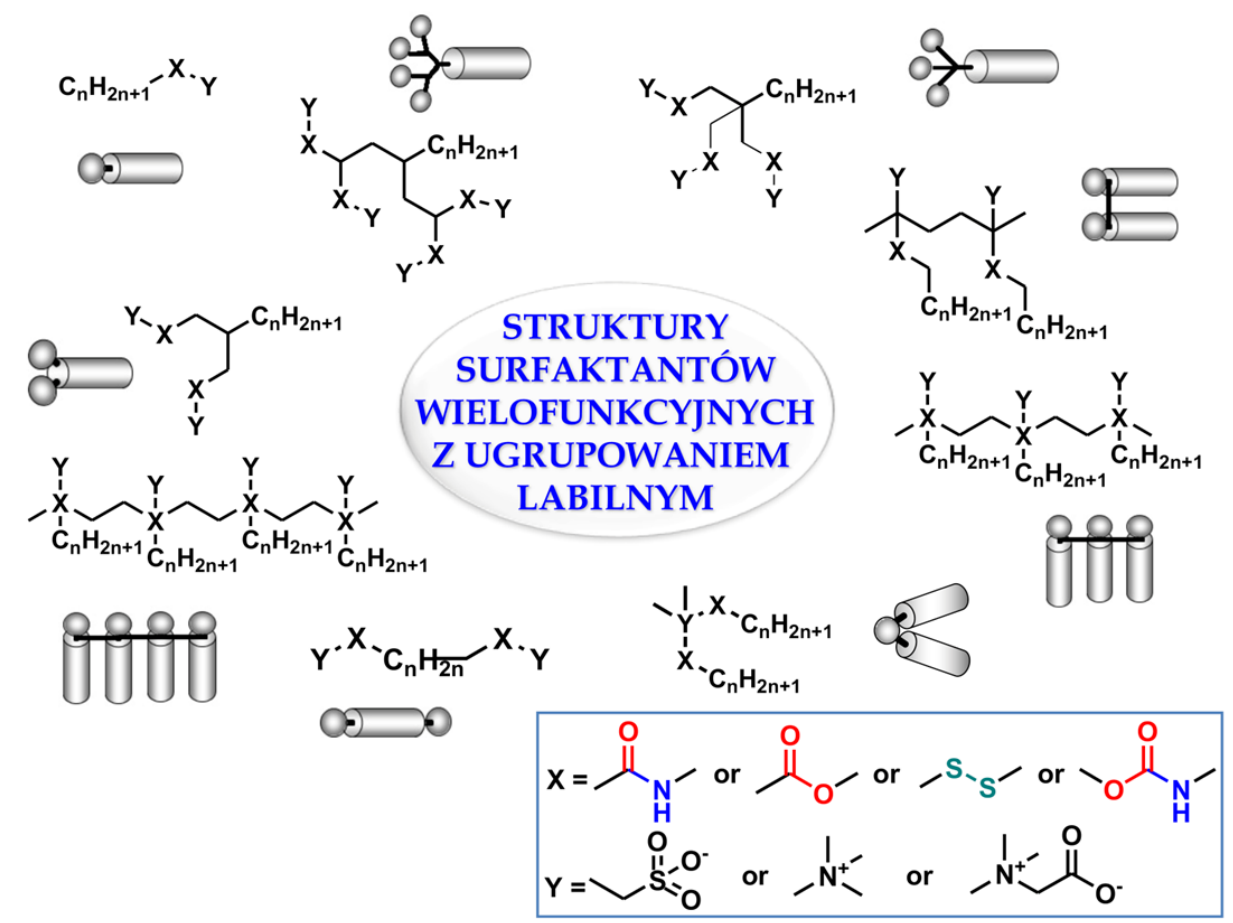

Rysunek 1. Struktury przykładowych surfaktantów wielofunkcyjnych z ugrupowaniem labilnym

Figure 1. Structures of exemplary multifunctional surfactants with labile moiety

\section{WIELOFUNKCYJNE SURFAKTANTY KATIONOWE}

Wielofunkcyjność w odniesieniu do surfaktantów wyraża się poprzez wprowadzenie do struktury dodatkowych ugrupowań hydrofilowych i/lub hydrofobowych, wspomnianych we wstępie ugrupowań labilnych (np. estrowe, amidowe, acetalowe, eterowe, disiarczkowe, fotochromowe etc.) czy węglowodanowych i oligopeptydowych [1,2]. Wielofunkcyjne surfaktanty kationowe o zadanych cechach użytkowych, w powiązaniu ze zwiększoną degradowalnością w środowisku i wzmożoną aktywnością biologiczną, spełniają 
współczesne wymagania racjonalnej gospodarki związkami chemicznymi i są elementem międzynarodowej polityki przemysłowej oraz ekologicznej [6]. Wydano szereg dyrektyw dotyczących związków powierzchniowo czynnych i ich oddziaływania na środowisko [7], a nowo wprowadzanym na rynek związkom stawia się coraz większe wymagania odnośnie oddziaływania na środowisko naturalne. Proekologiczne tendencje obejmują produkcję surfaktantów przyjaznych dla środowiska, do których zaliczyć można związki zawierające w cząsteczce labilne ugrupowania, gdyż ich obecność umożliwia rozkład cząsteczki na fragmenty nie wykazujące aktywności powierzchniowej (wspomniane wcześniej surfaktanty chemo(bio)degradowalne) (Rys. 2) [5]. Kluczową sprawą jest znalezienie korelacji pomiędzy specyficznymi właściwościami surfaktantu a jego strukturą, dlatego też w literaturze poświęcono temu zagadnieniu wiele uwagi [8-14].
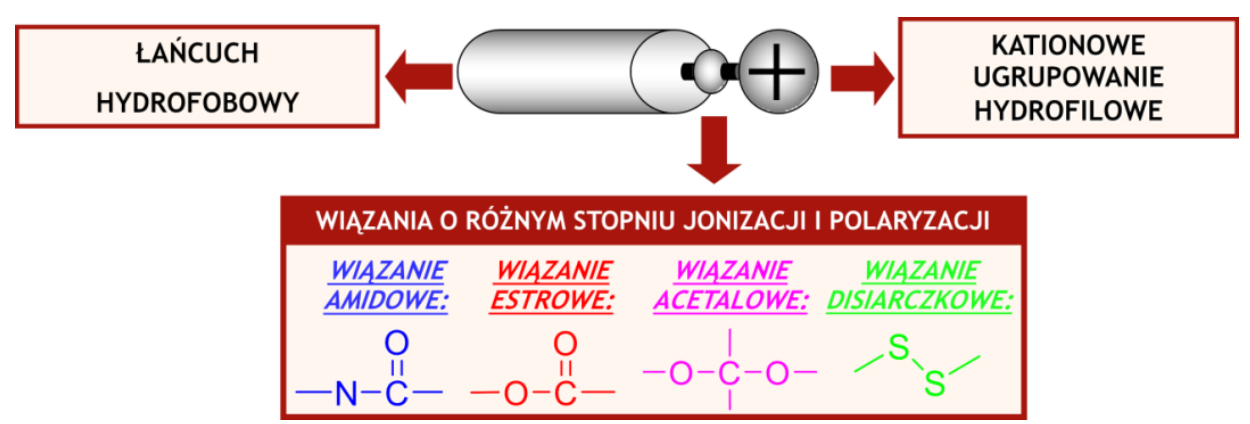

Rysunek 2. Uproszczony schemat budowy cząsteczek surfaktantów zawierających ugrupowania labilne Figure 2. A simplified structure of surfactants molecules containing labile moieties

Stosunkowo niewielkie modyfikacje budowy strukturalnej surfaktantu wielofunkcyjnego w odniesieniu do analogów konwencjonalnych, zawierających jedno ugrupowanie hydrofilowe i jedno hydrofobowe (sczepione razem bez łącznika), pozwalają uzyskać cenne spektrum unikatowych właściwości fizykochemicznych oraz użytkowych, a w efekcie ukierunkowanych zastosowań technologicznych [3,14-15]. Takie modyfikacje umożliwiają uzyskanie struktur zawierających przykładowo następującą architekturę: (i) jeden łańcuch hydrofobowy sczepiony ugrupowaniem labilnym $\mathrm{z}$ jednym ugrupowaniem hydrofilowym (np. surfaktanty chemodegradowalne o strukturze liniowej, ang. single tail-single head) [14]; (ii) dwa łańcuchy hydrofobowe - jedno ugrupowanie hydrofilowe (surfaktanty dwułańcuchowe, ang. dichain lub double tail surfactants) [16]; (iii) jeden łańcuch i więcej niż jedno ugrupowanie hydrofilowe (ang. multiple headgroups/multi-headed surfactants) [17], surfaktanty bolaamfifilowe zawierające dwa ugrupowania hydrofilowe umiejscowione na przeciwnych końcach łańcucha 
hydrofobowego [18], surfaktanty typu gemini, tzw.. surfaktanty bliźniacze lub dimeryczne zawierające dwie grupy hydrofilowe („głowy”) i dwa łańcuchy alkilowe oraz struktury oligomeryczne [19-22].

Wielofunkcyjne surfaktanty kationowe stanowią bardzo cenne czynniki budulcowe, których właściwości fizykochemiczne i cechy użytkowe, można prognozować/modyfikować poprzez zmianę struktury amfipatycznej związku i jego inkrustowanie ugrupowaniami reaktywnymi, by w rezultacie otrzymać tak zwane produkty specjalistyczne, istotne elementy składowe w szeregu procesów związanych ze strukturyzacją powierzchni międzyfazowej.

\section{WŁAŚCIWOŚCI UŻYTKOWE KATIONOWYCH SURFAKTANTÓW WIELOFUNKCYJNYCH}

Kationowe surfaktanty wielofunkcyjne ze względu na cechy strukturalne wykazują zarówno unikatowe zdolności do agregacji na granicach międzyfazowych i w fazie objętościowej, jak i specyficzne funkcje użytkowe w produktach specjalistycznych $[12,20]$. Ich rola często wiąże się z aktywnością biologiczną w stosunku do szerokiego spektrum bakterii, wirusów, grzybów czy glonów, w związku $\mathrm{z}$ tym mogą być zastosowane w środkach dezynfekcyjnych lub zabezpieczających przed pojawieniem się tego typu drobnoustrojów [23-26], a także jako inhibitory adhezji mikroorganizmów do powierzchni, efektywnie zapobiegając tworzeniu się biofilmu [27, 28]. Dzięki specyficznym właściwościom fizykochemicznym wiele związków amfifilowych, naturalnie występujących w przyrodzie i zawierających więcej niż jedno ugrupowanie hydrofilowe, spełnia ważne funkcje biologiczne [29], a ich syntetyczne odpowiedniki wykazują właściwości lecznicze [30, 31]. Dużo uwagi poświęcono w literaturze przedmiotu właściwościom solubilizacyjnym wielofunkcyjnych surfaktantów kationowych oraz ich zastosowaniu jako składników nowych leków, modelowych biomembran czy układów mikroheterogenicznych - mediów reakcyjnych, stanowiących swego rodzaju matryce $\mathrm{w}$ procesie preparowania różnego rodzaju nanostruktur [32, 33], w tym w systemach dostarczania leków i/lub czynników diagnostycznych [12, 34, 35]. Znajdują także zastosowania w procesach oczyszczania czy kondensacji DNA $[36,37]$, przy produkcji biosensorów i urządzeń bimolekularnych [38], czy jako czynniki restrukturyzujące w syntezie materiałów mezoporowatych [39]. Kationowe surfaktanty wielofunkcyjne dobrze adsorbują się na ujemnie naładowanych powierzchniach i wykazują doskonałe właściwości antyelektrostatyczne [40, 41]. W procesach flotacji mogą spełniać rolę zbieraczy, a w katalizie mogą być stosowane jako katalizatory przeniesienia międzyfazowego [42-44] lub templaty do syntezy zeolitów [45]. 
Ostatnio ukazała się znaczna liczba prac traktujących o surfaktantach kationowych, w większości dotyczących opisu zależności pomiędzy strukturą chemiczną związku a jego naturą i właściwościami na granicach międzyfazowych [20, 46-49]. Charakterystyczną zaletą stosowania surfaktantów kationowych w wielu recepturach jest ich wysoka aktywność przy niewielkim udziale procentowym. W bilansie światowej produkcji związki kationowe zajmują mniej ważne miejsce jeżeli chodzi o skalę ich wytwarzania [50], jest jednak faktem bezspornym, że są one nie do zastąpienia w wielu zastosowaniach.

\section{ADSORPCJA SURFAKTANTÓW NA GRANICY FAZ CIECZ/GAZ}

Adsorpcja jest jednym z podstawowych zjawisk powierzchniowych. Proces ten polega na samorzutnym gromadzeniu się cząsteczek na granicy faz, prowadząc do obniżenia energii powierzchniowej wyrażającej się zmianą napięcia powierzchniowego lub międzyfazowego.

Podstawowym równaniem do opisu procesu adsorpcji surfaktantów na granicy międzyfazowej, jest równanie Gibbsa:

$$
\Gamma_{i}=-\frac{a_{i}}{R T}\left(\frac{\partial \gamma}{\partial a_{i}}\right)_{T, P}
$$

w którym:

$\Gamma_{i}$ - względny nadmiar powierzchniowy cząsteczek surfaktantu $\left[\mathrm{mol} / \mathrm{m}^{2}\right]$,

$\gamma$ - napięcie powierzchniowe [N/m],

$a_{i}$-aktywność związku powierzchniowo czynnego $\left[\mathrm{mol} / \mathrm{dm}^{3}\right]$,

$R$ - stała gazowa $[\mathrm{J} / \mathrm{mol} \cdot \mathrm{K}]$,

$T$ - temperatura $[\mathrm{K}]$.

Dla roztworów rozcieńczonych można przyjąć, że współczynniki aktywności są bliskie jedności, a stąd aktywność substancji rozpuszczonej jest równa stężeniu, $a_{i} \approx c_{i}$ i wówczas przybliżone równanie Gibbsa przyjmuje postać:

$$
\Gamma_{i}=-\frac{c_{i}}{R T}\left(\frac{\partial \gamma}{\partial c_{i}}\right)_{T, P}
$$

Równanie to wiąże zmiany napięcia powierzchniowego $\mathrm{z}$ nadmiarem powierzchniowym, który $\mathrm{w}$ przypadku surfaktantów jest bliski stężeniu powierzchniowemu, a zmianami stężenia objętościowego [51, 52]. Jeżeli $\partial \gamma / \partial c_{i}<0$, wówczas $\Gamma_{\mathrm{i}}>0$. Oznacza to, że substancja rozpuszczona gromadzi się na powierzchni i powoduje obniżenie napięcia powierzchniowego. W sytuacji odwrotnej, gdy $\partial y / \partial c_{i}>0$ substancja rozpuszczona jest usuwana $z$ granicy faz 
i wciągana w głąb fazy objętościowej $\left(\Gamma_{\mathrm{i}}<0\right.$, adsorpcja ujemna). Z równania Gibbsa wynika możliwość ilościowego określenia wielkości nadmiaru powierzchniowego $\Gamma_{\mathrm{i}}$ obliczając pochodną $\left(\partial \gamma / \partial c_{i}\right)_{\mathrm{T}, \mathrm{P}}$, zależności $\gamma=f\left(c_{i}\right)$ otrzymanej na podstawie pomiarów doświadczalnych. Dla jonowych związków powierzchniowo czynnych w równaniu Gibbsa uwzględnia się ko-adsorpcję przeciwjonów (ze względu na warunek elektroneutralności) poprzez użycie współczynnika $n$, określającego liczbę jonów obecnych w roztworze:

$$
\Gamma_{i}=-\frac{c_{i}}{n R T}\left(\frac{\partial \gamma}{\partial c_{i}}\right)_{T, P}
$$

Dla związków dysocjujących na jednowartościowy jon surfaktantu i jednowartościowy przeciwjon $n=2$. Dla całkowicie zdysocjowanych wieloładunkowych jonów surfaktantu współczynnik $\mathrm{n}$ jest równy liczbie przeciwjonów surfaktantu powiększony o jeden (dla jednowartościowych przeciwjonów) [53].

Kinetyka procesu adsorpcji jest związana $\mathrm{z}$ transportem cząsteczki $\mathrm{z}$ fazy objętościowej do granicy międzyfazowej. Obszar sąsiadujący $\mathrm{z}$ fazą powierzchniową, będący $\mathrm{z}$ nią $\mathrm{W}$ równowadze, nazywany jest czasem podpowierzchnią ( $\mathrm{z}$ ang. subsurface). W wyniku istnienia gradientu stężeń cząsteczki związku powierzchniowo aktywnego $\mathrm{z}$ fazy objętościowej migrują najpierw do obszaru podpowierzchni, a dopiero później do granicy międzyfazowej. Transport cząsteczek z fazy objętościowej do podpowierzchni odbywa się na drodze dyfuzji konwekcyjnej [54,55] i jest procesem, który zachodzi samorzutnie, natomiast transfer pomiędzy podpowierzchnią a granicą międzyfazową może być kontrolowany kinetycznie [55]. Generalnie, metody doświadczalne dają makroskopowy obraz adsorpcji surfaktantów na granicy faz, natomiast szczegółowe dane dotyczące rozkładu jonów w warstwie dyfuzyjnej mogą być otrzymane tylko na drodze rozważań teoretycznych, które dla surfaktantów jonowych są dość skomplikowane ze względu na wieloskładnikową naturę takich układów.

\section{TEORETYCZNE MODELE ADSORPCJI JONOWYCH SURFAKTANTÓW}

Do opisu adsorpcji surfaktantów na granicach faz ciecz/gaz lub ciecz/ciecz najczęściej stosuje się modele (izotermy) Langmuira [56], Frumkina [57] lub Helfanda, Frisha i Lebovitza (HFL) [58,59]. Modele te dobrze opisują adsorpcję pojedynczych surfaktantów niejonowych za pomocą niewielkiej liczby dopasowywalnych parametrów. Opis adsorpcji jonowych surfaktantów na granicy faz ciecz/gaz jest bardziej skomplikowany, ponieważ ich wodne roztwory są 
z natury układami wieloskładnikowymi, zawierającymi zarówno aktywne powierzchniowo jony surfaktantu, przeciwjony, jak również jony pochodzące od elektrolitów dodawanych $\mathrm{w}$ celu ustalenia siły jonowej lub $\mathrm{pH}$ roztworu. W literaturze istnieje wiele modeli teoretycznych, które w mniej lub bardziej dokładny sposób opisują zjawisko adsorpcji jonowych surfaktantów na ciekłych granicach międzyfazowych. Podstawowym problemem podejścia modelowego jest w miarę poprawny opis oddziaływań elektrycznych. Obecność surfaktantów jonowych na granicy faz powoduje powstawanie podwójnej warstwy elektrycznej (PWE), której potencjał ma wpływ na swobodną energię ich adsorpcji. Na potencjał podwójnej warstwy elektrycznej, a zwłaszcza jej części zwartej, zwanej też warstwą Sterna [60], ma wpływ stopień jej penetracji przez przeciwjony. Do opisu adsorpcji surfaktantów jonowych można zastosować jedną ze znanych izoterm (np. Frumkina), której parametry będą zależeć od warunków eksperymentalnych (np. od siły jonowej roztworu). Jednakże podejście takie nie daje możliwości opisu zjawisk elektrycznych na granicy międzyfazowej, w szczególności wyznaczenia zależności potencjału PWE od stężenia surfaktantu. Alternatywną metodą opisu adsorpcji jonowych surfaktantów jest uwzględnienie explicite obecności PWE na granicy międzyfazowej. Po raz pierwszy podejście to zostało zaproponowane przez Daviesa i Rideala [61], w którym adsorpcję jonów surfaktantu rozważali w oparciu o izotermę Langmuira, a do opisu PWE zastosowali teorię Gouy-Chapmana. Model ten został rozszerzony przez Borwankara i Wasana [62, 63], którzy zastosowali izotermę Frumkina do opisu adsorpcji powierzchniowo aktywnych jonów. Oba wspomniane modele zakładają, że jony surfaktantu adsorbują się na granicy faz $\mathrm{w}$ warstwie Sterna, natomiast przeciwjony pozostają w warstwie dyfuzyjnej podwójnej warstwy elektrycznej (Rys. 3), a potencjał powierzchniowy zależy wyłącznie od ładunku jonów surfaktantu zaadsorbowanych na powierzchni międzyfazowej i od siły jonowej roztworu.

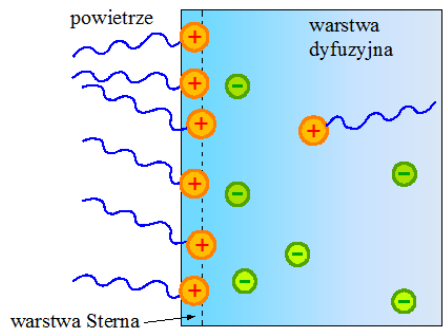

Rysunek 3. Model adsorpcji kationowych surfaktantów według Daviesa-Rideala-Borwankara-Wasana [61-63]

Figure 3. The model of adsorption of cationic surfactants according to Davies-Rideal-Borwankar-Wasan [61-63] 
Model ten nie wyjaśnia, obserwowanego eksperymentalnie, specyficznego wpływu różnego rodzaju przeciwjonów na napięcia powierzchniowe roztworów surfaktantów jonowych, co więcej, w dużej mierze zawyża potencjał PWE w porównaniu z wartościami mierzonymi. W związku z tym Kalinin i Radke [64] zaproponowali podejście oparte na koncepcji Grahama struktury PWE [65]. Założyli, że częściowo dehydratowane przeciwjony mogą tworzyć pary z jonami surfaktantu, a ich centra są położone w wewnętrznej warstwie Helmholtza, różnej od tej, w której znajdują się zaadsorbowane głowy surfaktantu. Natomiast całkowicie hydratowane przeciwjony w dyfuzyjnej części PWE mogą penetrować aż do zewnętrznej warstwy Helmholtza [64]. Według tego modelu potencjał powierzchniowy zależy od liczby wolnych (niesparowanych) jonów surfaktantu na powierzchni międzyfazowej oraz od siły jonowej roztworu. (Rys. 4).

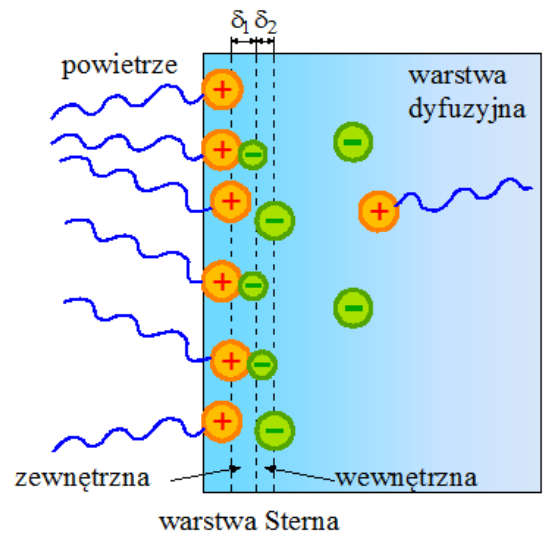

Rysunek 4. Model adsorpcji surfaktantów kationowych według Kalinina-Radke [64]; $\delta_{1} \mathrm{i} \delta_{2}$ oznaczają odpowiednio grubość wewnętrznej i zewnętrznej warstwy Helmholtza

Figure 4. The model of cationic surfactant adsorption according to Kalinin-Radke [64]; $\delta 1$ and $\delta 2$ represent the thickness of the inner and outer Helmholtz layers, respectively

Podobne podejście uwzględniające tworzenie się par jonów na powierzchni międzyfazowej zaproponowali Kralchevsky i współpracownicy [66] oraz Danov i współpracownicy [67], którzy zmodyfikowali model Borwankara-WasanaKalinina-Radke przyjmując, że przeciwjony o określonej wielkości mogą łączyć się z jonowymi głowami cząsteczek surfaktantu. Ich termodynamiczne rozważania dotyczyły również mieszanin jonowych i niejonowych surfaktantów w obecności różnych soli. Fainerman i Lucassen-Reynders [68, 69] zaproponowali model termodynamiczny, uwzględniający poprawki dla współczynników aktywności roztworów elektrolitów i opisali izotermy napięcia powierzchniowego wybranych kationowych i anionowych surfaktantów w obecności dodanej soli. Jednakże ich rozważania nie obejmowały specyficznego wpływu jonów na adsorpcję surfaktan- 
tów jonowych, nie wyznaczali oni również potencjału powierzchniowego. Ivanov i współpracownicy dokonali porównania modeli adsorpcji surfaktantów jonowych wykorzystujących izotermy Langmuira, Frumkina, Volmera i HFL [59]. Warszyński i współpracownicy zaproponowali model kwazi-dwuwymiarowego elektrolitu ( $\mathrm{z}$ ang. surface quasi-two-dimensional electrolyte, STDE) do opisu adsorpcji jonowych surfaktantów [70-72], jako alternatywnego do modelu KalininaRadke. Model ten zakłada, że przeciwjony mogą, na skutek silnego pola elektrycznego, penetrować warstwę Sterna traktowaną jako kwazi-dwuwymiarowy elektrolit, w którym nie jest spełniony warunek elektroobojętności (Rys. 5). Całkowity ładunek w warstwie Sterna jest sumą ładunków dodatnich pochodzących od zaadsorbowanych jonów i ładunków ujemnych pochodzących od przeciwjonów. Ładunek ten określa potencjał warstwy dyfuzyjnej. Model uwzględnia efektywny rozmiar jonowych grup funkcyjnych surfaktantu i przeciwjonów, a także oddziaływania między nimi. Po raz pierwszy model STDE zastosowano do opisu izoterm napięcia powierzchniowego oraz izoterm potencjału powierzchniowego dodecylosiarczanu sodu (SDS) w obecności $\mathrm{NaCl}$ [70]. Następnie ulepszono model poprzez uwzględnienie oddziaływań bocznych w warstwie Sterna i zastosowano go do opisu równowagowych izoterm napięcia powierzchniowego różnych roztworów decylosiarczanów alkalicznych [71]. Model STDE zastosowano ponadto do opisu adsorpcji surfaktantów kationowych o różnych przeciwjonach [46, 72, 73], jak również do opisu elastyczności powierzchniowej roztworów bromku cetylotrimetyloamoniowego (CTABr) przy różnych stężeniach surfaktantu [74]. Szczegółowy opis modelu STDE oraz jego zastosowanie dla jonów jednowartościowych przedstawiono w publikacjach $[46,73]$.

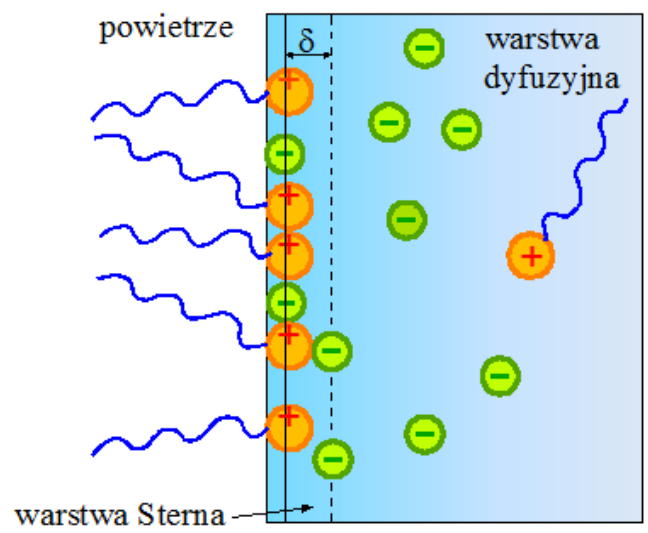

Rysunek 5. Model kwazidwuwymiarowego elektrolitu zaproponowany przez Warszyńskiego i współpracowników; $\delta$ określa grubość warstwy Sterna

Figure 5. Quasi-two dimensional electrolyte model of ionic surfactant adsorption proposed by Warszynski et al.; $\delta$ - the Stern layer thickness. 
Matematyczną postać równania adsorpcji dla jonów surfaktantu oraz innych jonów obecnych w roztworze można otrzymać z warunku równowagi, tj., poprzez przyjęcie równości potencjałów elektrochemicznych dla wszystkich jonów obecnych w roztworze i w warstwie Sterna. W modelu STDE do wyznaczenia potencjału chemicznego składników w warstwie Sterna wykorzystuje się równanie Frumkina (model dwuwymiarowego roztworu regularnego) [46, 70, 71] lub HFL (model oddziałujących sztywnych dysków) [59]. Model STDE został również zastosowany do opisu układów mieszanych, adsorpcji mieszanin surfaktantów jonowych i niejonowych [75], surfaktantów pH czułych, których ładunek zależy od protonacji [76], chemodegradowalnych dla których produkty degradacji różnią się aktywnością powierzchniową, jak i dla adsorpcji surfaktantów wieloładunkowych dla których istnieje możliwość tworzenia asocjatów jon surfaktantu-przeciwjon. Dla przykładu dla surfaktantów kationowych o ładunku $z_{s} e$ równania opisujące adsorpcję mają postać [19]:

$$
\frac{a_{S}}{\alpha_{S}}\left(-\frac{z_{s} e \psi_{s}}{k T}\right)\left(1-\theta_{S}-\theta_{S A}-\theta_{C 1}-\theta_{C 2}\right)=\theta_{S} \exp \left[-2 H_{S}\left(\theta_{S}+\theta_{S A}\right)\right] \exp \left(\frac{\phi_{S}}{k T}\right)
$$

dla jonów surfaktantu (S),

$$
\frac{a_{S A}}{\alpha_{S}}\left(-\frac{z_{S A} e \psi_{S}}{k T}\right)\left(1-\theta_{S}-\theta_{S A}-\theta_{C 1}-\theta_{C 2}\right)=\theta_{S A} \exp \left[-2 H_{S}\left(\theta_{S}+\theta_{S A}\right)\right] \exp \left(\frac{\phi_{S}}{k T}\right)
$$

dla asocjatów jon surfaktantu-przeciwjon $z_{S A}=z_{S}-1$,

$$
\begin{gathered}
\frac{a_{C 1}}{\alpha_{C 1}}\left(\frac{z_{C 1} e \psi_{s}}{k T}\right)\left(1-\theta_{S}-\theta_{C 1}-\theta_{C 2}\right)^{g c 1 s}=\theta_{C 1} \exp \left(\frac{\phi_{C 1}}{k T}\right) \\
\frac{a_{C 2}}{\alpha_{C 2}}\left(\frac{z_{C 2} e \psi_{s}}{k T}\right)\left(1-\theta_{S}-\theta_{C 1}-\theta_{C 2}\right)^{g c 2 s}=\theta_{C 2} \exp \left(\frac{\phi_{C 2}}{k T}\right)
\end{gathered}
$$

dla przeciwjonów surfaktantu $(\mathrm{C} 1)$ oraz anionów dodanego elektrolitu $(\mathrm{C} 2)$.

We wzorach tych $a_{i}=\gamma_{i} c_{i}$ wyraża aktywność jonów surfaktantu oraz przeciwjonów $\mathrm{w}$ roztworze, $\gamma_{i}$ wyraża współczynniki aktywności, natomiast $c_{i}$ stężenia poszczególnych składników. $z_{i}$ jest wartościowością danego jonu, $\alpha_{S}$ wyraża aktywność powierzchniową jonów surfaktantu i jest miarą swobodnej energii adsorpcji po odseparowaniu wkładu od oddziaływań elektrycznych, $\alpha_{C}$ jest pozorną ,aktywnością powierzchniową" przeciwjonów, będącą miarą ich penetracji do warstwy Sterna, w przypadku anionów skorelowaną z ich polaryzowalnością [46]. Względne stężenia powierzchniowe surfaktantu i asocjatów jon surfaktantuprzeciwjon wyrażane są wzorami:

$$
\theta_{S}=\frac{\Gamma_{S}}{\Gamma_{S \infty}}, \theta_{S A}=\frac{\Gamma_{S A}}{\Gamma_{S \infty}}
$$


w których $\Gamma_{\mathrm{S} \infty}$ jest granicznym stężeniem powierzchniowym surfaktantu w maksymalnie upakowanej monowarstwie; analogicznie dla przeciwjonów:

$$
\theta_{C 1}=\frac{\Gamma_{C 1}}{\Gamma_{C 1 \infty}}, \theta_{C 2}=\frac{\Gamma_{C 2}}{\Gamma_{C 2 \infty}}
$$

w których $\Gamma_{\mathrm{C} 1 \infty} \mathrm{i} \Gamma_{\mathrm{C} 2 \infty}$ mają to samo znaczenie dla przeciwjonów i jonów dodanego elektrolitu; $g$ wyraża stosunek maksymalnych nadmiarów powierzchniowych dla jonów surfaktantów i przeciwjonów w monowarstwie, zależnych od wielkości naładowanej grupy hydrofilowej i rozmiarów jonów:

$$
g_{C 1 S}=\frac{\Gamma_{S \infty}}{\Gamma_{C 1 \infty}}, g_{C 2 S}=\frac{\Gamma_{S \infty}}{\Gamma_{C 2 \infty}}
$$

natomiast $H_{\mathrm{S}}$ jest parametrem związanym $\mathrm{z}$ oddziaływaniami pomiędzy hydrofobowymi łańcuchami zaadsorbowanych cząsteczek surfaktantu.

Potencjał elektryczny w warstwie Sterna, $\psi_{s}$, można wyznaczyć z równania:

$$
\psi_{s}=\psi_{d}+\frac{\sigma \delta}{\varepsilon_{0} \varepsilon_{s}}
$$

gdzie:

$$
\sigma=F\left(z_{s} \Gamma_{S}+z_{s A} \Gamma_{S A}+z_{C 1} \Gamma_{C 1}+z_{C 2} \Gamma_{C 2}\right)
$$

jest ładunkiem powierzchniowym pochodzącym od wszystkich jonów zaadsorbowanych $\mathrm{w}$ warstwie Sterna, $\psi_{d}$ potencjałem elektrycznym na granicy warstwy Sterna i dyfuzyjnej części podwójnej warstwy elektrycznej, $\delta$ i $\varepsilon_{S}$ grubością i stałą dielektryczną warstwy Sterna, a $\varepsilon_{0}$ - przenikalnością dielektryczną próżni. Dla układu, w którym znajdują się wieloładunkowe jony surfaktantu bądź elektrolitu nie ma wzoru analitycznego wyrażającego związek gęstości ładunku powierzchniowego $\mathrm{z}$ potencjałem $\psi_{d}$, dlatego wyznacza się go metodami numerycznymi, zgodnie z zależnością:

$$
\sigma=\sqrt{\varepsilon_{0} \varepsilon k T N_{A}\left(\sum_{i} c_{i}\left(\exp \left[-\frac{z_{i} e \psi_{d}}{k T}\right]-1\right)\right)}
$$

w której: $F$ jest stałą Faraday'a, $N_{\mathrm{A}}$ liczbą Avogadro, $\varepsilon$ - stała dielektryczną fazy objętościowej (dla wody $\varepsilon=79$ ). 
Poprawkę opisującą aktywność jonów w dwuwymiarowej warstwie elektrolitu $\varphi_{i}$, uwzględniającą oddziaływania pomiędzy jonami można wyznaczyć ze wzoru:

$$
\frac{\phi_{i}}{k T}=-\frac{e^{2}}{8 \pi \varepsilon_{0} \varepsilon_{s} k T} \frac{\kappa_{s}}{1+\kappa_{s} a_{s i}}
$$

w którym:

$$
\kappa_{s}=\frac{e^{2}\left(z_{S}^{2} \Gamma_{S}+z_{S A}^{2} \Gamma_{S A}+z_{C 1}^{2} \Gamma_{C 1}+z_{C 2}^{2} \Gamma_{C 2}\right)}{\varepsilon_{0} \varepsilon_{s} k T}
$$

jest dwuwymiarowym, powierzchniowym odpowiednikiem długości DebyeHückel'a, natomiast $a_{s i}$ oznacza efektywny promień jonowy w warstwie międzyfazowej. Całkowite stężenie powierzchniowe wszystkich jonów obecnych w roztworze oblicza się uwzględniając ich adsorpcję w dyfuzyjnej części podwójnej warstwy elektrycznej według wzoru:

$$
\Gamma_{i}^{E D L}=\frac{c_{i}}{\kappa} \int_{0}^{\psi_{d}} \frac{\exp \left[-\frac{z_{i} e \psi}{k T}\right]-1}{s(\psi)} d \psi
$$

w którym:

$$
s(\psi)=\sqrt{\frac{2 e^{2} N_{A}}{\varepsilon_{0} \varepsilon k T \kappa^{2}} \sum_{i}\left(c_{i} \exp \left[-\frac{z_{i} e \psi_{d}}{k T}\right]-1\right)},
$$

a $\kappa$ jest odwrotnością długości Debye-Hückel'a. Po wyznaczeniu całkowitego stężenia powierzchniowego dla jonów surfaktantu i innych jonów obecnych w roztworze, napięcie powierzchniowe można wyznaczyć całkując równanie izotermy Gibbsa, które dla surfaktantów jonowych przyjmuje następującą postać:

$$
-d \gamma=\Gamma_{S^{+}}^{T} d \mu_{S^{+}}+\Gamma_{S A^{+}}^{T} d \mu_{S A^{+}}+\Gamma_{C 1^{-}}^{T} d \mu_{C 1^{-}}+\Gamma_{K^{+}}^{T} d \mu_{K^{+}}+\Gamma_{C 2^{-}}^{T} d \mu_{C 2^{-}}
$$

$\Gamma^{\mathrm{T}}$ - całkowite stężenia powierzchniowe dla jonów surfaktantu $\left(\mathrm{S}^{+}\right)$, asocjatów $\left(\mathrm{SA}^{+}\right)$, przeciwjonów $\left(\mathrm{Cl}^{-}, \mathrm{C}^{-}\right)$i ko-jonów $\left(\mathrm{K}^{+}\right)$obejmujące również jony w dyfuzyjnej części PWE, $\mu$ 's, $\mu_{i}=\mu_{i 0}+R T \ln \left(a_{i}\right)$, wyrażają odpowiednie potencjały chemiczne, a $\mu_{i 0}$ jest standardowym potencjałem chemicznym danego jonu. Dla ko-jonów rozpatrywana jest wyłącznie negatywna adsorpcja w dyfuzyjnej 
części PWE. Model STDE można również wyprowadzić w oparciu o izotermę HFL wykorzystując geometryczne rozmiary grup hydrofilowych i przeciwjonów dla przewidzenia wartości parametrów $\Gamma_{s \infty}, \Gamma_{c \infty}$.

Teoretyczny model adsorpcji jonowych surfaktantów STDE daje możliwość obliczenia przebiegu izoterm napięcia powierzchniowego $\mathrm{w}$ funkcji stężenia surfaktantu oraz wyznaczenia stężeń powierzchniowych wszystkich rodzajów jonów obecnych w roztworze, jak również elektrycznego potencjału warstwy Sterna oraz dyfuzyjnej części podwójnej warstwy elektrycznej.

\section{AKTYWNOŚĆ POWIERZCHNIOWA DWUFUNKCYJNYCH SURFAKTANTÓW KATIONOWYCH TYPU SOLI AMONIOWYCH}

Wśród wielu znanych surfaktantów jonowych funkcjonalizowane czwartorzędowe sole amoniowe należą do grupy najintensywniej badanych związków [19,20], [26,37]. Struktury dwufunkcyjne zawierające dwie "głowy” hydrofilowe i jeden hydrofobowy „ogon” (ang. dicephalic, double-headed) znane są od dawna, choć termin "dicephalic” został wprowadzony dopiero w 1998 roku przez Sommerdijka dla amfifilowych pochodnych imidazolowych i fosforowych [77] i określa grupę związków z dwoma ramionami zdolnymi między innymi do kompleksowania jonów metali. Z uwagi na to, że cząsteczka takiego związku składa się z jednego ugrupowania hydrofobowego i dwóch polarnych ramion przypominających rodzaj „kleszczy”, związki te określa się również mianem związków o budowie kleszczowej. W porównaniu ze standardowymi strukturami, surfaktanty zawierające co najmniej dwie "głowy” wykazują znaczny charakter hydrofilowy. Prowadzi to do zmniejszenia aktywności powierzchniowej i wpływa na unikalne właściwości $\mathrm{w}$ stanie zagregowanym. Przykładem kleszczowych surfaktantów dwufunkcyjnych są dibromki $N, N$-bis(3,3'trimetyloammoniopropylo)alkilamidów $\mathrm{C}_{\mathrm{n}}(\mathrm{TAPABr})_{2}$ oraz dimetylosiarczany (VI) $\mathrm{N}, \mathrm{N}$-bis(3,3'-trimetyloammoniopropylo)alkilamidów $\quad \mathrm{C}_{\mathrm{n}}$ (TAPAMS), $\quad$ których metodę syntezy opisano w [78]. Struktury surfaktantów przedstawiono na Rys. 6. Obecność w strukturze ugrupowania amidowego wiążącego hydrofobowy łańcuch węglowodorowy z dwudodatnią grupą hydrofilową zawierającą czwartorzędowe aminy pozwala zaliczyć te surfaktanty do klasy chemodegradowalnych.

Na Rys. 7 przedstawiono równowagowe izotermy napięcia powierzchniowego dla badanych dibromków $N, N$-bis(3,3'-trimetyloammoniopropylo)alkilamidów $\mathrm{Cn}(\mathrm{TAPABr})_{2}$ oraz dimetylosiarczanów $N, N$-bis(3,3'-trimetyloammoniopropylo)alkilamidów Cn(TAPAMS $)_{2}$. Liniami ciągłymi zaznaczono krzywe teoretyczne uzyskane na podstawie modelu kwazi-dwuwymiarowego elektrolitu (STDE), natomiast punkty przedstawiają dane eksperymentalne [79]. 
<smiles>C[C@H](Br)C(=O)N(CCC[N+](C)(C)Br)CCC[N+](C)(C)Br</smiles>

$\operatorname{Cn}(\mathrm{TAPABr})_{2} ; \mathrm{n}=9,11,13,15$<smiles>CCCCCC[C@H](OS(=O)(=O)O[Na])C(=O)N(CCC[N+](C)(C)C)CCC[N+](C)(C)C</smiles>

$\operatorname{Cn}\left(\right.$ TAPAMS $_{2} ; \mathrm{n}=9,11,13,15$

Rysunek 6. Struktury badanych kationowych surfaktantów dwufunkcyjnych - bromków i metylosiarczanów diamoniowych

Figure 6. Structure of studied cationic dicephalic surfactants - bisammonium bromides and methyl sulfates

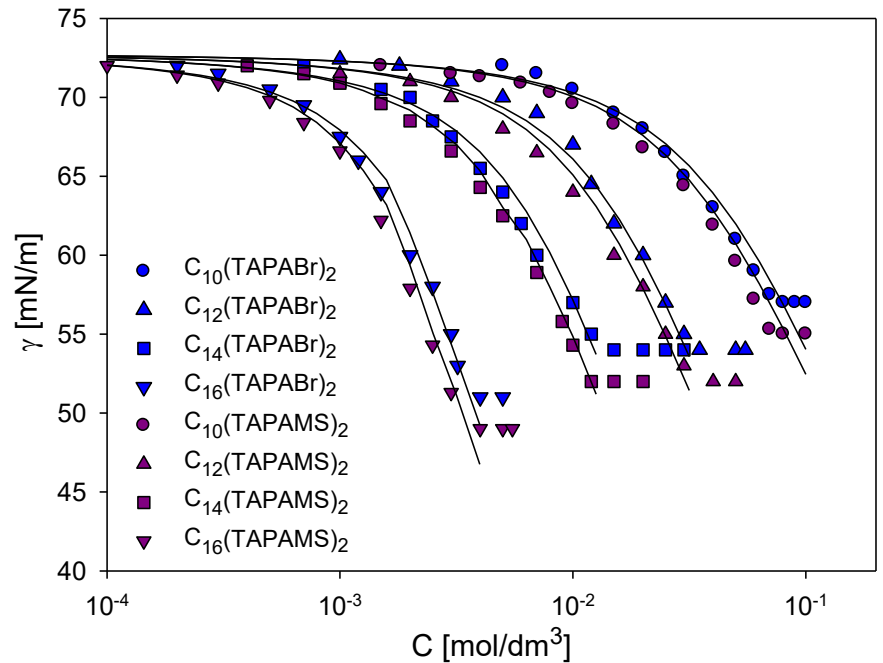

Rysunek 7. Zależność napięcia powierzchniowego $(\gamma)$ od stężenia dla dibromków $\mathrm{Cn}(\mathrm{TAPABr})_{2}$ i dimetylosiarczanów $\mathrm{Cn}(\mathrm{TAPAMS})_{2}$ dwufunkcyjnych ( $\left.\mathrm{n}=10,12,14,16\right)$; liniami ciągłymi zaznaczono krzywe uzyskane na podstawie teoretycznego modelu adsorpcji surfaktantów jonowych (STDE) [79]

Figure 7. Surface tension $(\gamma)$ of dicephalic dibromides $\mathrm{Cn}(\mathrm{TAPABr})_{2}$ and dimethylsulfates $\left.\mathrm{Cn}(\mathrm{TAPAMS})_{2}(n) 10,12,14,16\right)$ as a function of surfactant concentration; lines represent fits of the theoretical model of ionic surfactant adsorption to experimental data. Reprinted with permission from [79]. Copyright (2010) American Chemical Society

Uzyskane zależności napięcia powierzchniowego świadczą o klasycznym zachowaniu surfaktantów na granicy faz ciecz/gaz. Wzrost długości łańcucha alkilowego $\mathrm{w}$ obu szeregach homologicznych powoduje wzrost aktywności powierzchniowej badanych związków. Widoczne jest, że model teoretyczny STDE 
dobrze opisuje wyniki doświadczalne dla procesu adsorpcji badanych soli bisamoniowych na swobodnej powierzchni. W tabeli 1 podane zostały wartości parametrów najlepszego dopasowania surfaktantów dwufunkcyjnych oraz ich liniowych odpowiedników - bromku 3-[(trimetyloammonio)-propylo] dodekanamidu $\left(\mathrm{C}_{12} \mathrm{TAPABr}\right)$ i metylosiarczanu 3-[(trimetyloammonio)propylo]dodekanamidu ( $\mathrm{C}_{12}$ TAPAMS $)$.

Pochodne metylosiarczanowe są nieco bardziej aktywne powierzchniowo niż odpowiadające im pochodne bromkowe. Różnice w aktywności badanych związków można wyjaśnić w oparciu o zastosowany do opisu teoretycznego model STDE dla wieloładunkowych jonów surfaktantu. Proces adsorpcji surfaktantów jonowych zależy od rodzaju ich przeciwjonów [46,71]. Specyficzny wpływ różnego typu anionów na adsorpcję surfaktantów kationowych wynika $\mathrm{z}$ różnej ich zdolności do penetracji warstwy Sterna [46,49]. Aniony, które wykazują większe powinowactwo do warstwy powierzchniowej, bardziej efektywnie neutralizują ładunek zaadsorbowanych cząsteczek surfaktantu i zmniejszają potencjał powierzchniowy podwójnej warstwy elektrycznej (PWE). W rezultacie częściowej neutralizacji ładunku zmniejsza się elektrostatyczne odpychanie pomiędzy cząsteczkami w fazie powierzchniowej i objętościowej i w rezultacie więcej cząsteczek surfaktantu ulega zaadsorbowaniu. Dzięki zastosowaniu modelu STDE istnieje możliwość skorelowania jednego z parametrów modelu, wyrażającego „aktywność powierzchniową” przeciwjonu surfaktantu, $\alpha_{c}, \mathrm{z}$ jego zdolnością do penetracji warstwy Sterna. Im niższa jest wartość parametru $\alpha_{c}$, tym łatwiej przeciwjony penetrują warstwę Sterna. Oznacza to, że w obecności jonów surfaktantu, przeciwjony metylosiarczanowe $\left(\alpha_{\mathrm{CH}_{3} \mathrm{OSO}_{3}}{ }^{-}=2300\left[\mathrm{~mol} / \mathrm{dm}^{3}\right]\right)$ wykazują nieco wyższe powinowactwo do warstwy powierzchniowej niż jony bromkowe $\left(\alpha_{\mathrm{Br}}{ }^{-}=2800\left[\mathrm{~mol} / \mathrm{dm}^{3}\right]\right)$. W związku z tym jony metylosiarczanowe bardziej efektywnie neutralizują ładunek podwójnej warstwy elektrycznej, ułatwiają adsorpcję jonów surfaktantu i wpływają na silniejsze obniżenie napięcia powierzchniowego. Zgodnie $\mathrm{z}$ danymi literaturowymi [46], zdolność różnych anionów do wspomagania adsorpcji surfaktantów kationowych zmienia się w szeregu: $\mathrm{F}^{-}<\mathrm{CH}_{3} \mathrm{COO}^{-}<\mathrm{Cl}^{-}<\mathrm{Br}^{-}<\mathrm{NO}_{3}^{-}<\mathrm{I}^{-}<\mathrm{ClO}_{4}^{-}$, który pokrywa się $\mathrm{z}$ szeregiem Hofmeistera. Symulacje metodą dynamiki molekularnej przeprowadzone dla elektrolitów typu 1:1, zawierających jony halogenkowe [8082] potwierdzają, że silniej spolaryzowane aniony wykazują tendencję do gromadzenia się $\mathrm{w}$ warstwie powierzchniowej wskutek oddziaływań z polem elektrycznym na powierzchni międzyfazowej. Tendencja ta zmienia się zgodnie z szeregiem Hofmeistera i potwierdza wnioski wyciągnięte na podstawie modelu STDE dotyczące wpływu różnych anionów na adsorpcję surfaktantów kationowych. Wartość parametru $\alpha_{c}$ dla jonów metylosiarczanowych wskazuje na 
ich nieco silniejsze oddziaływanie $\mathrm{z}$ polem elektrycznym na powierzchni międzyfazowej niż jonów $\mathrm{NO}_{3}{ }^{-}\left(\alpha_{\mathrm{NO} 3}{ }^{-}=2500\left[\mathrm{~mol} / \mathrm{dm}^{3}\right]\right)$ i jonów $\mathrm{Br}^{-}\left(\alpha_{\mathrm{Br}}{ }^{-}=2800\right.$ $\left.\left[\mathrm{mol} / \mathrm{dm}^{3}\right]\right)$, natomiast słabsze niż jonów I- $\left(\left(\alpha_{\mathrm{CH} 3 \mathrm{OSO} 3^{-}}=450\left[\mathrm{~mol} / \mathrm{dm}^{3}\right]\right)[46]\right.$. W literaturze brak jest doniesień odnośnie polaryzowalności jonów metylosiarczanowych, jednakże uzyskana wartość parametru $\alpha_{\mathrm{CH} 30 \mathrm{OS}_{3}}{ }^{-}=2300$ $\left[\mathrm{mol} / \mathrm{dm}^{3}\right]$, wydaje się być rozsądna przy założeniu, że polaryzowalność jonów metylosiarczanowych powinna być większa od polaryzowalności jonów $\mathrm{HSO}_{4}{ }^{-}$ (których aktywność powierzchniowa jest porównywalna do aktywności jonów $\mathrm{Cl}^{-}$) ze względu na ich większe rozmiary. Hipotezę o wyższej aktywności jonów metylosiarczanowych względem jonów bromkowych potwierdzają pomiary napięć powierzchniowych dla liniowych odpowiedników związków dwufunkcyjnych bromku 3-[(trimetyloammonio)-propylo]dodekanamidu $\quad \mathrm{C}_{12} \mathrm{TAPABr}$ i metylosiarczanu 3-[(trimetyloammonio)-propylo]dodekanamidu $\mathrm{C}_{12}$ TAPAMS; uzyskane wyniki przedstawiono na Rys. 8., a parametry najlepszego dopasowania dla modelu STDE zestawiono w Tabeli 1. 
Tabela 1. Parametry najlepszego dopasowania ${ }^{a}$ modelu teoretycznego do izoterm doświadczalnych dla badanych surfaktantów dwufunkcyjnych oraz ich liniowych odpowiedników [79]

Table 1. Fitting parameters ${ }^{a}$ of the theoretical model to the surface tension isotherms of the studied dicephalic cationic surfactants and their linear standards [79]

\begin{tabular}{|c|c|c|c|c|c|c|c|c|}
\hline Związek & $\alpha_{S}\left(\mathbf{m o l} / \mathbf{d m}^{3}\right)$ & $\begin{array}{c}\boldsymbol{H}_{S} \\
(\mathbf{k J} / \mathbf{m o l})\end{array}$ & $\begin{array}{c}10^{6} \Gamma_{S} \\
\left(\mathrm{~mol} / \mathrm{cm}^{2}\right)\end{array}$ & $\begin{array}{c}A_{\min } \\
\left(\mathrm{nm}^{2}\right)\end{array}$ & $\underset{(\mathrm{kJ} / \mathrm{mol})}{\Delta G_{\text {ads }}^{0}}$ & $\varepsilon$ & $\begin{array}{c}K \\
\left(\mathrm{dm}^{3} / \mathrm{mol}\right)\end{array}$ & $\begin{array}{c}\mathrm{cmc}^{b} \\
\left(\mathbf{m o l} / \mathbf{d m}^{3}\right)\end{array}$ \\
\hline $\mathrm{C}_{10}(\mathrm{TAPABr})_{2}$ & $4.5 \times 10^{-4}$ & 0.5 & 3.4 & 0.49 & -18.90 & 27 & 5 & $8.0 \times 10^{-2}$ \\
\hline $\mathrm{C}_{12}(\mathrm{TAPABr})_{2}$ & $3.6 \times 10^{-5}$ & 0.5 & 3.4 & 0.49 & -25.10 & 26 & 5 & $3.5 \times 10^{-2}$ \\
\hline $\mathrm{C}_{14}(\mathrm{TAPABr})_{2}$ & $4.4 \times 10^{-6}$ & 0.5 & 3.4 & 0.49 & -30.25 & 25 & 5 & $1.5 \times 10^{-2}$ \\
\hline $\mathrm{C}_{16}(\mathrm{TAPABr})_{2}$ & $2.9 \times 10^{-7}$ & 1.0 & 3.4 & 0.49 & -36.92 & 22.5 & 5 & $4.0 \times 10^{-3}$ \\
\hline $\mathrm{C}_{10}(\mathrm{TAPAMS})_{2}$ & $4.5 \times 10^{-4}$ & 0.5 & 3.4 & 0.49 & -18.90 & 27 & 7 & $7.5 \times 10^{-2}$ \\
\hline $\mathrm{C}_{12}(\text { TAPAMS })_{2}$ & $3.6 \times 10^{-5}$ & 0.5 & 3.4 & 0.49 & -25.10 & 26 & 7 & $3.0 \times 10^{-2}$ \\
\hline $\mathrm{C}_{14}(\mathrm{TAPAMS})_{2}$ & $4.4 \times 10^{-6}$ & 0.5 & 3.4 & 0.49 & -30.25 & 25 & 7 & $1.0 \times 10^{-2}$ \\
\hline $\mathrm{C}_{16}(\text { TAPAMS })_{2}$ & $2.9 \times 10^{-7}$ & 1.0 & 3.4 & 0.49 & -36.92 & 22.5 & 7 & $3.5 \times 10^{-3}$ \\
\hline $\mathrm{C}_{12} \mathrm{TAPABr}$ & $1.6 \times 10^{-5}$ & 4.9 & 5.4 & 0.31 & -27.08 & 26.5 & - & $1.2 \times 10^{-2}$ \\
\hline $\mathrm{C}_{12}$ TAPAMS & $1.6 \times 10^{-5}$ & 4.9 & 5.4 & 0.31 & -27.08 & 26.5 & - & $1.0 \times 10^{-2}$ \\
\hline
\end{tabular}

${ }^{a}$ Dalsze parametry: $\alpha_{\mathrm{Br}}{ }^{-}=2800\left[\mathrm{~mol} / \mathrm{dm}^{3}\right], \alpha_{\mathrm{CH} 30 \mathrm{OO}}{ }^{-}=2300\left[\mathrm{~mol} / \mathrm{dm}^{3}\right], \delta=a_{\mathrm{Br}}{ }^{-}=0.33[\mathrm{~nm}], \delta=a_{\mathrm{CH} 30 \mathrm{OO}}{ }^{-}=0.35[\mathrm{~nm}]$.

${ }^{b}$ Wartości cmc (krytycznego stężenia micelizacji) wyznaczono na podstawie izoterm przedstawionych na Rys. 7. 


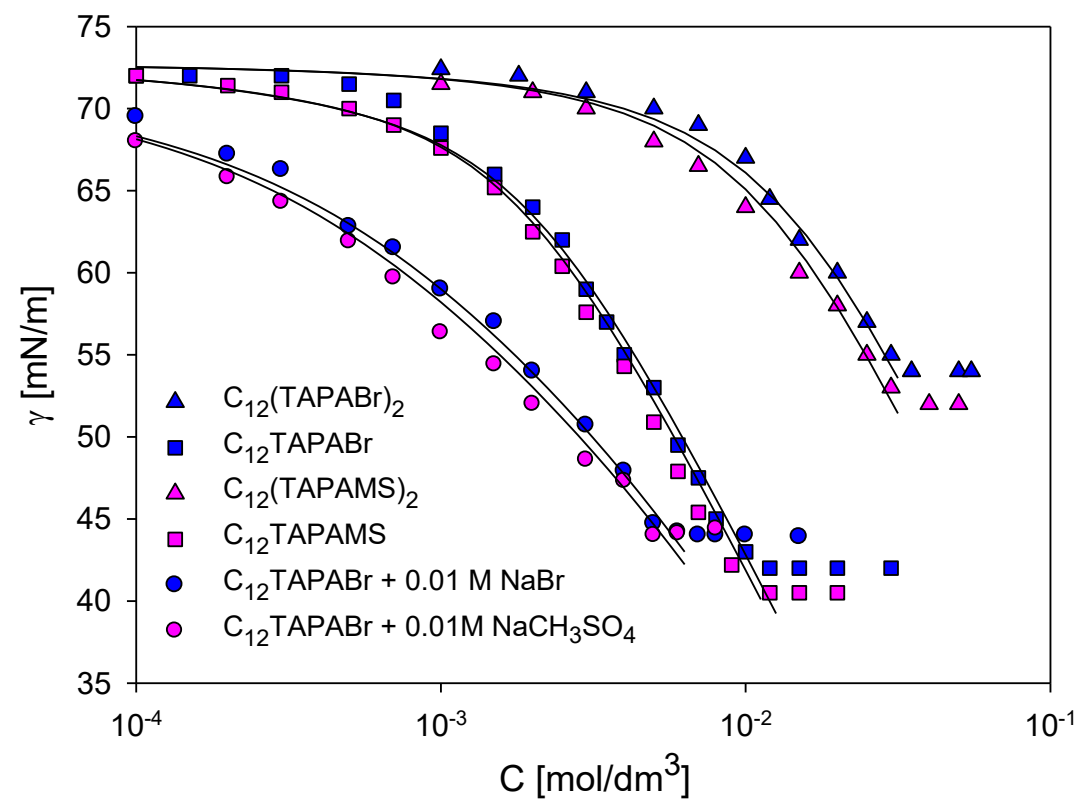

Rysunek 8. Zależność napięcia powierzchniowego $(\gamma)$ od stężenia dla związków dwufunkcyjnych $\mathrm{C}_{12}(\mathrm{TAPABr})_{2}$ i $\mathrm{C}_{12}(\mathrm{TAPAMS})_{2}$ oraz ich liniowych odpowiedników $\mathrm{C}_{12} \mathrm{TAPABr}$

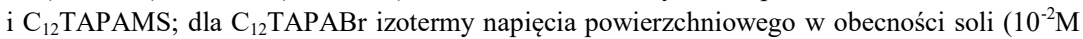
$\mathrm{NaBr}$ i $10^{-2} \mathrm{M} \mathrm{NaCH}_{3} \mathrm{SO}_{4}$ ); liniami ciągłymi zaznaczono krzywe uzyskane na podstawie modelu STDE [79]

Figure 8. Surface tension $(\gamma)$ of dicephalic compounds $\mathrm{C} 12(\mathrm{TAPABr})_{2}$ and $\mathrm{C} 12(\mathrm{TAPAMS})_{2}$ and their linear equivalents $\mathrm{C} 12 \mathrm{TAPABr}$ and $\mathrm{C} 12 \mathrm{TAPAMS}$ as a function of surfactant concentration; surface tension $(\gamma)$ of $\mathrm{C} 12 \mathrm{TAPABr}$ in the presence of added salts $\left(10^{-2} \mathrm{M} \mathrm{NaBr}\right.$ and $\left.\mathrm{NaCH}_{3} \mathrm{SO}_{4}\right)$ as a function of surfactant concentration; solid lines denote theoretical curves (STDE model). Reprinted with permission from [79]. Copyright (2010) American Chemical Society

Zaprezentowane izotermy wskazują, że surfaktanty liniowe o tej samej długości łańcucha alkilowego są bardziej aktywne powierzchniowo niż surfaktanty dwufunkcyjne, a zgodnie z przedstawioną hipotezą we wszystkich przypadkach pochodne metylosiarczanowe wykazują nieco wyższą aktywność powierzchniową niż odpowiadające im pochodne bromkowe. Hipotezę tą dodatkowo potwierdziły pomiary napięć powierzchniowych dla liniowego bromku $\mathrm{C}_{12} \mathrm{TAPABr}$ przy stałym stężeniu dwóch soli: $10^{-2} \mathrm{M} \mathrm{NaBr}$ i $10^{-2} \mathrm{M} \mathrm{NaCH}_{3} \mathrm{SO}_{4}$ (Rys. 5.3). Uzyskane wyniki pokazują, że dodatek elektrolitu powoduje spadek napięcia powierzchniowego i w obecności jonów metylosiarczanowych spadek ten jest większy niż w obecności takiego samego stężenia jonów bromkowych. Przeciwjony bromkowe surfaktantu $\mathrm{C}_{12} \mathrm{TAPABr}$ są przynajmniej częściowo zastępowane na powierzchni międzyfazo- 
wej przez bardziej aktywne powierzchniowo jony metylosiarczanowe. Podobne zjawisko zastępowania anionów obserwowano dla surfaktantów CTABr i CTACl w obecności roztworów $\mathrm{KCl}$ i $\mathrm{KBr}$ [46]. Dodatek $\mathrm{KBr}$ do roztworów wyżej wymienionych surfaktantów powoduje większy spadek napięcia powierzchniowego niż dodatek takiego samego stężenia $\mathrm{KCl}$.

O różnicy $\mathrm{w}$ aktywności powierzchniowej badanych związków świadczą wartości standardowych energii adsorpcji, $\Delta G_{\text {ads, }}^{0}$, zestawione w Tabeli 1. Bardziej ujemne wartości $\Delta G_{\text {ads }}^{0}$ dla surfaktantów $\mathrm{C}_{12} \mathrm{TAPABr}$ i $\mathrm{C}_{12}$ TAPAMS świadczą o ich wyższej tendencji do adsorbowania się na granicy międzyfazowej w porównaniu ze związkami dwufunkcyjnymi. Na Rys. 9 została przedstawiona

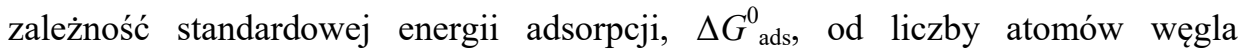
w łańcuchu alkilowym, $n_{\mathrm{C}}$, dla obu badanych szeregów homologicznych soli bisamoniowych.

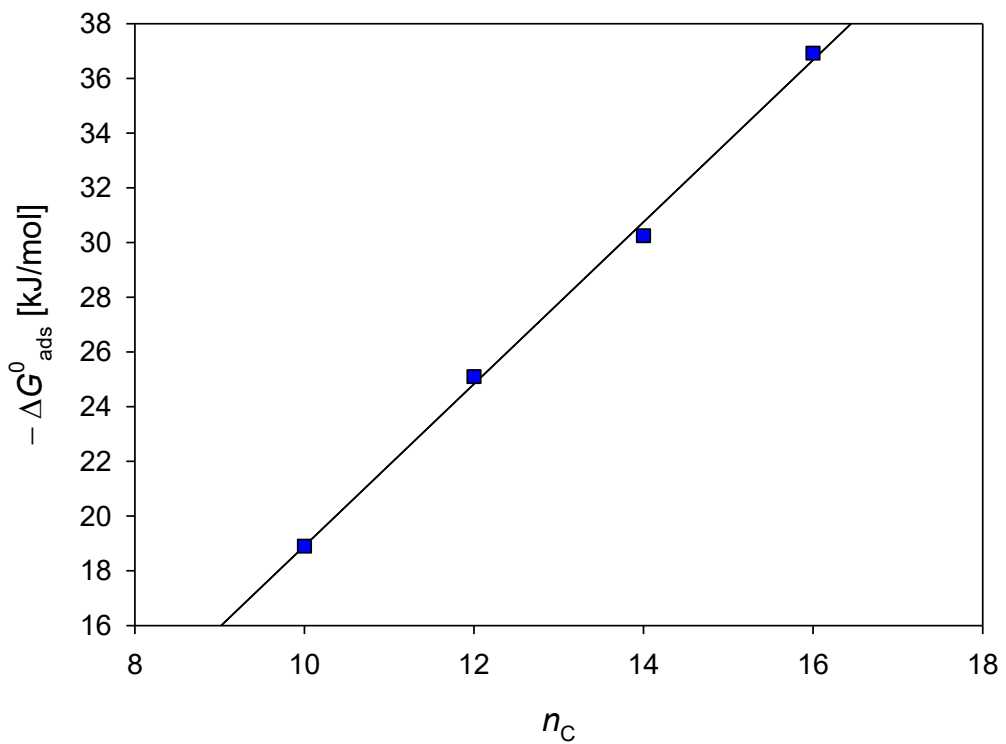

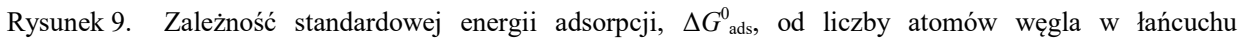
alkilowym, $n_{\mathrm{C}}$, dla $\mathrm{Cn}(\mathrm{TAPABr})_{2}$ i $\mathrm{Cn}(\mathrm{TAPAMS})_{2}$

Figure 9. Dependence of the standard free energy of adsorption, $\Delta G_{\text {ads }}^{0}$, on the number of carbon atoms, $\mathrm{n}_{\mathrm{C}}$, for homologues series of $\mathrm{Cn}(\mathrm{TAPABr})_{2}$ and $\mathrm{Cn}(\mathrm{TAPAMS})_{2}$

Wartości standardowych energii adsorpcji zostały wyznaczone z zależności:

$$
\Delta G_{a d s}^{0}=R T \ln \left(\alpha_{S}\right)
$$

w której $\alpha_{\mathrm{S}}$ oznacza aktywność powierzchniową jonów surfaktantu wyznaczoną na podstawie modelu STDE. Przedstawiona na Rys. 9 liniowa zależność standardowej 
energii adsorpcji od liczby atomów węgla $\mathrm{w}$ łańcuchu alkilowym jest zgodna z regułą Traubego dla szeregów homologicznych surfaktantów i dla badanych związków dwufunkcyjnych może być przedstawiona następującym równaniem:

$$
\Delta G_{a d s}^{0}=-2.96 n_{C}+10.69
$$

w którym współczynnik korelacji $R^{2}=0.998$.

Minimalna powierzchnia przypadająca na cząsteczkę surfaktantu w warstwie adsorpcyjnej, $A_{\min }$, została obliczona z zależności $A_{\min }=\frac{1}{N_{A} \Gamma_{m}}$, przy czym wartość nadmiaru powierzchniowego, $\Gamma_{\mathrm{m}}$, została wyznaczona na podstawie modelu STDE. Dla surfaktantów zawierających jedną „głowę” i jeden „ogon” uzyskano niższe wartości parametru $A_{\min }$ W stosunku do surfaktantów dwufunkcyjnych. Parametr ten praktycznie nie zmienia się wraz ze wzrostem ugrupowania hydrofobowego dla danego szeregu homologicznego.

Obecność w cząsteczce dwóch hydrofilowych „głów” powoduje wzrost odległości pomiędzy łańcuchami zaadsorbowanych w warstwie powierzchniowej cząsteczek surfaktantu i zmniejszenie bocznych oddziaływań pomiędzy nimi, co też potwierdza niska wartość parametru $H_{\mathrm{S}}$ (Tabela 1) określającego siłę oddziaływań hydrofobowych łańcuchów w warstwie adsorpcyjnej. Jedynie w przypadku pochodnych zawierających 16 atomów węgla w łańcuchach hydrofobowych można zauważyć słabe oddziaływania między nimi. Podobnie niskie wartości parametru $H_{\mathrm{S}}$, wyznaczonego na podstawie modelu STDE, zaobserwowano dla soli bis- i trisamoniowych, przykładowo dla dichlorków bis[2-hydroxy-3-(dodecylodimetyloammonio)propylo]alkiloamin $\quad\left(\right.$ bis $\left.\mathrm{AmC}_{12}\right) \mathrm{C}_{2}$ i trichlorków bis[2-hydroxy-3(dodecylodimetyloammonio)propylo]dialkiloamoniowych $\left(\right.$ tris $\left.\mathrm{Ambis}_{12}\right) \mathrm{C}_{2}$ o różnej długości łącznika [19]. W przypadku liniowych surfaktantów kationowych - bromków dodecylotrialkiloamoniowych (DDTABr, DDTEABr, DDTPABr, DDTBABr), bromków typu gemini - bromki $N, N, N$, $N$ '-tetrametylo- $N, N$ 'di(dodecylo)alkilenodiamoniowe (d(DDA)Ebr, d(DDA)PBr, d(DDA)BBr) [83], parametr oddziaływań hydrofobowych jest znacznie wyższy w porównaniu ze związkami dwufunkcyjnymi i dimerycznymi lub trimerycznymi chlorkami amoniowymi [37]. Ponadto dla surfaktantów różniących się wielkością ugrupowania hydrofilowego, bromków dodecylotrialkiloamoniowych [83], wartość parametru $H_{\mathrm{S}}$ maleje wraz ze wzrostem hydrofilowej „głowy”. Związki te cechuje również zbliżona wartość minimalnej powierzchni przypadającej na jedną cząsteczkę w warstwie adsorpcyjnej, $A_{\min }$, do wartości uzyskanej dla związków dwufunkcyjnych $\left(\mathrm{Cn}(\mathrm{TAPABr})_{2} \quad\right.$ i $\left.\mathrm{Cn}(\mathrm{TAPAMS})_{2}\right)$ i związków gemini (d(DDA)Ebr, d(DDA)PBr, d(DDA)BBr) [83], podczas gdy związki (bisAmC $\left.{ }_{12}\right) \mathrm{Cn}$ 
i (trisAmbisC $\left.\mathrm{C}_{12}\right) \mathrm{Cn}(\mathrm{n}=2,6)$ [19] wykazują ponad dwukrotnie wyższe wartości parametru $A_{\text {min, }}$ wynikające z ich budowy geometrycznej.

W przypadku surfaktantów dwufunkcyjnych, podobnie jak i oligomerycznych [19] czyli takich, które posiadają więcej niż jedno ugrupowanie hydrofilowe obdarzone ładunkiem, istnieje możliwość tworzenia się kompleksów w układzie jon surfaktantu-przeciwjon, które w znaczny sposób wpływają na właściwości powierzchniowe roztworów tych związków. Dlatego też teoretyczne izotermy napięcia powierzchniowego dla wszystkich badanych surfaktantów dwufunkcyjnych $\left(\mathrm{Cn}(\mathrm{TAPABr})_{2}\right.$ i $\left.\mathrm{Cn}(\mathrm{TAPAMS})_{2} ; \mathrm{n}=10,12,14,16\right)$ wyznaczane na podstawie modelu STDE uwzględniają wieloładunkowy charakter jonów surfaktantu oraz tworzenie się asocjatów w układzie jon surfaktantu-przeciwjon. Proces ten można opisać w oparciu o prawo działania mas:

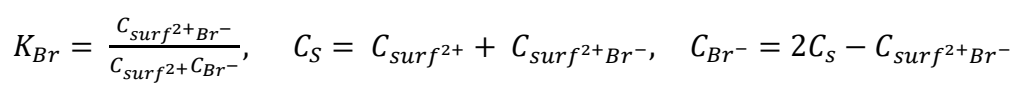

w którym $K_{\mathrm{Br}}$ oznacza stałą asocjacji (w przypadku jonów $\mathrm{Br}^{-}$), $C_{\mathrm{s}}$ - całkowite stężenie jonów surfaktantu, $C_{\text {surf2+ }}$ - stężenie całkowicie zdysocjowanych jonów surfaktantu, $C_{\text {surf2+Br- }}$ - stężenie asocjatów, $C_{\mathrm{Br}}$ - stężenie jonów bromkowych w roztworze. Najlepszy opis teoretyczny eksperymentalnych izoterm $\mathrm{Cn}(\mathrm{TAPABr})_{2}$ i $\mathrm{Cn}(\mathrm{TAPAMS})_{2}$ został uzyskany odpowiednio dla $\mathrm{K}_{\mathrm{Br}}=5 \mathrm{dm}^{3} / \mathrm{mol} \mathrm{i}_{\mathrm{MS}}=7$ $\mathrm{dm}^{3} / \mathrm{mol}$. Na Rys. 10 przedstawiono zmianę stężenia dwuładunkowych jonów surfaktantu, wolnych jonów bromkowych oraz kompleksów jon surfaktantu przeciwjon bromkowy wraz ze wzrostem stężenia surfaktantu, wyznaczone na podstawie rozszerzonego modelu STDE $\mathrm{z}$ równania 5.3. Wraz ze wzrostem całkowitego stężenia $\mathrm{C}_{12}(\mathrm{TAPABr})_{2}$ w roztworze relatywnie maleje stężenie dwudodatnich jonów surfaktantu $\left(\operatorname{Surf}^{2+}\right)$ oraz swobodnych anionów bromkowych $\left(\mathrm{Br}^{-}\right)$, natomiast stopniowo rośnie stężenie ich asocjatów $\left(\mathrm{Surf}^{2+} \mathrm{Br}^{-}\right)$, co powoduje wzrost aktywności powierzchniowej roztworu.

Hipotezę tworzenia się kompleksów jon surfaktantu - przeciwjon potwierdzono zarówno za pomocą metod modelowania molekularnego, które bardziej szczegółowo opisano w [79], jak również poprzez pomiary stężenia wolnych jonów bromkowych w roztworach $\mathrm{z}$ użyciem jonoselektywnej elektrody bromkowej. Wyniki uzyskanych pomiarów przykładowo dla pochodnej $\mathrm{C}_{12}(\mathrm{TAPABr})_{2}$ przedstawiono na Rys. 11. 


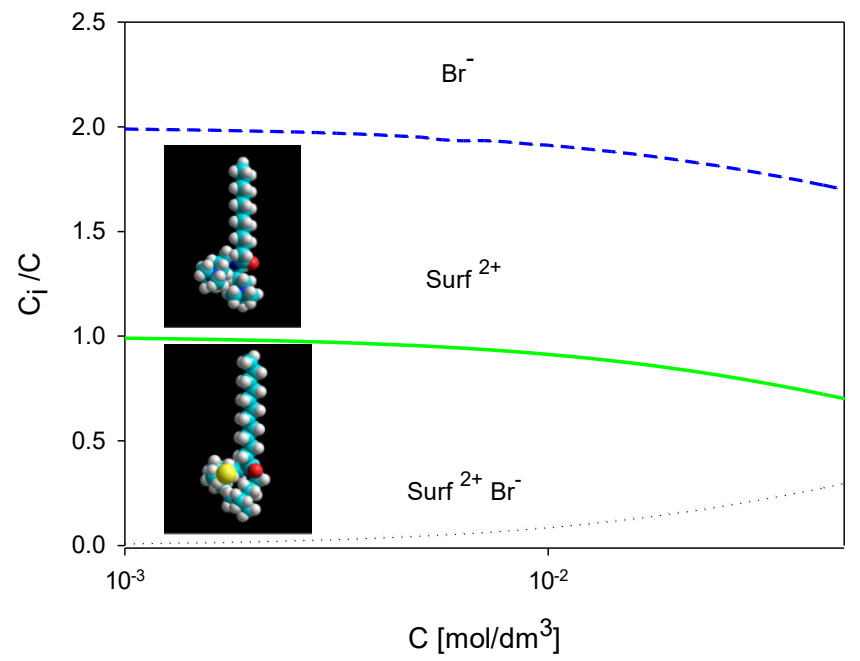

Rysunek 10. Względne stężenia dwuładunkowych jonów surfaktantu, wolnych jonów bromkowych oraz asocjatów jon surfaktantu - przeciwjon w funkcji całkowitego stężenia surfaktantu $\mathrm{C}_{12}(\mathrm{TAPABr})_{2}$ wyznaczone z równania 5.3 [79]

Figure 10. Relative amounts of divalent surfactant ions, bromine ions, and surfactant-bromide associates as a function of total surfactant concentration for $\mathrm{C} 12(\mathrm{TAPABr})_{2}$ calculated according to eq 5.3 . Adapted with permission from [79]. Copyright (2010) American Chemical Society

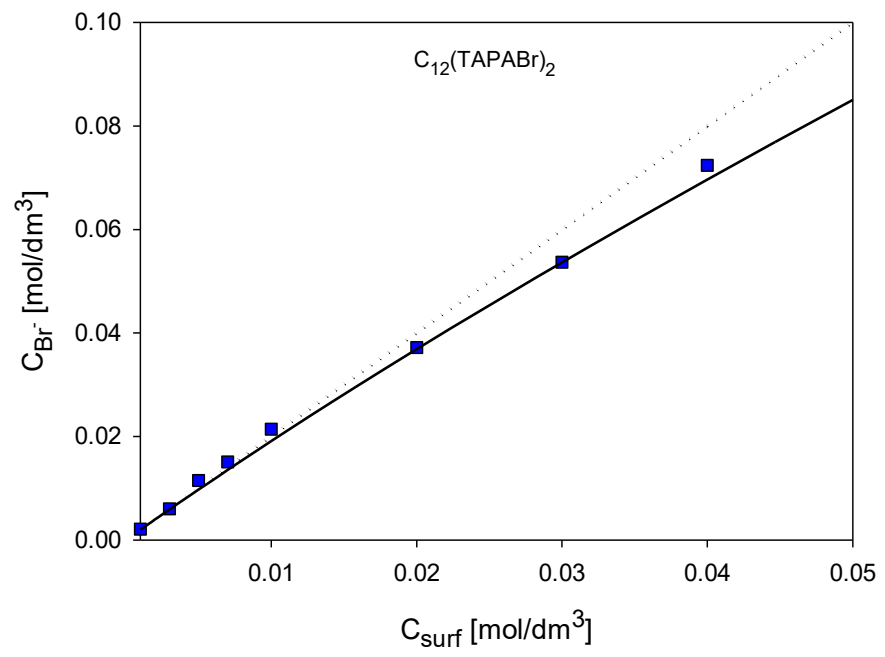

Rysunek 11. Stężenie jonów bromkowych w roztworze $\mathrm{C}_{12}(\mathrm{TAPABr})_{2} \mathrm{w}$ funkcji stężenia surfaktantu; dane eksperymentalne zaznaczono punktami. Linia ciągła przedstawia krzywą teoretyczną wyznaczoną na podstawie równania 5.3, linia przerywana - hipotetyczne stężenie jonów bromkowych przy pełnej dysocjacji surfaktantu [79]

Figure 11. Concentration of bromide ions in the solution of $\mathrm{C} 12(\mathrm{TAPABr})_{2}$ as a function of surfactant concentration. Symbols denote experimental data, the solid line represents the theoretical dependence calculated according to eq 5.3, and the dotted line represents the hypothetical dependence in the absence of surfactant-counterion associates. Reprinted with permission from [79]. Copyright (2010) American Chemical Society 
Przy niskich stężeniach surfaktantu stężenie jonów bromkowych jest dwukrotnie większe, co odpowiada pełnej dysocjacji soli bis-amoniowych, natomiast przy wyższych stężeniach, ale nadal niższych niż krytyczne stężenie micelizacji (cmc) badanych surfaktantów, rzeczywiste stężenie jonów $\mathrm{Br}^{-}$jest niższe niż przewidywane dla całkowitej dysocjacji surfaktantu, co wskazuje na tworzenie się asocjatów w układzie jon surfaktantu - przeciwjon. Prowadzi to do częściowej neutralizacji ładunku grup hydrofilowych $\mathrm{w}$ warstwie powierzchniowej $\mathrm{i}$ do wzrostu adsorpcji wskutek zmniejszenia odpychających oddziaływań elektrostatycznych pomiędzy zaadsorbowanymi jonami surfaktantu. Wyniki doświadczalne bardzo dobrze opisuje krzywa teoretyczna, zaznaczona na Rys. 11 linią ciągłą, uzyskana na podstawie równania 5.3 przy wartości stałej asocjacji dla najlepszego dopasowania (patrz Tabela 1).

Model STDE pozwala na opis izoterm surfaktantów dwufunkcyjnych w szerokim zakresie stężeń za pomocą ograniczonej liczby parametrów. Trzy $\mathrm{z}$ nich, $H_{\mathrm{S}}, \Gamma_{\mathrm{m}}$ i $\alpha_{\mathrm{S}}$, odnoszą się tylko i wyłącznie do jonów surfaktantu [46, 70, 72], zatem ich fizyczne znaczenie powiązane jest bezpośrednio z izotermą adsorpcji dla związku niejonowego o takiej samej długości łańcucha alkilowego jak dla badanych surfaktantów jonowych. Wartość maksymalnego nadmiaru powierzchniowego, $\Gamma_{\mathrm{m}}$, zależy od wielkości ugrupowania hydrofilowego. Pozostaje stała dla wszystkich badanych związków dwufunkcyjnych, natomiast różni się dla związków liniowych $\mathrm{C}_{12} \mathrm{TAPABr}$ i $\mathrm{C}_{12}$ TAPAMS i surfaktantów oligomerycznych [19]. Wartości parametru $\alpha_{\mathrm{S}}$ (Tabela 5.1) określają aktywność powierzchniową jonów surfaktantu. Podobnie jak w przypadku tego parametru dla przeciwjonów, $\alpha_{\mathrm{C}}$, im niższa jest wartość parametru $\alpha_{\mathrm{S}}$, tym wyższa aktywność powierzchniowa poszczególnych związków. W obliczeniach teoretycznych przyjęto, że efektywny promień jonowy w warstwie powierzchniowej, $\alpha_{\mathrm{Br}}{ }^{-}$i $\alpha_{\mathrm{CH} 30 \mathrm{OSO}}{ }^{-}$, determinuje grubość warstwy Sterna, $\delta$. Jeśli chodzi o wartość stałej dielektrycznej w warstwie Sterna, $\varepsilon_{\mathrm{S}}$, to brak jest bezpośredniej metody jej pomiaru, jednakże wartość uzyskana na podstawie modelu STDE wydaje się być rozsądna. Zaobserwowano niewielki spadek wartości $\varepsilon_{S}$ wraz ze wzrostem długości łańcucha alkilowego, co jest zgodne z wynikami opisanymi $\mathrm{w}$ [83]. Wartość $\varepsilon_{\mathrm{S}}=22.5$ dla $\mathrm{C}_{16}(\mathrm{TAPABr})_{2} \mathrm{i}_{16}(\mathrm{TAPAMS})_{2}$ jest zbliżona do wartości stałych dielektrycznych wnętrza micel dla $\mathrm{CTABr}\left(\varepsilon_{\mathrm{m}}=16\right)$ i CTACl $\left(\varepsilon_{\mathrm{m}}=18\right)$ wyznaczonych metodami fluorescencyjnymi przez $\mathrm{K}$. Kalyanasundarama i J.K. Thomasa [84] Niewielka różnica może wynikać z faktu, że wewnątrz micel hydrofobowe łańcuchy są bardziej upakowane niż w warstwie powierzchniowej, co ogranicza penetrację wody do wnętrza micel i prowadzi do uzyskania niższych wartości stałych dielektrycznych. Opis teoretyczny izoterm surfaktantów dwufunkcyjnych za pomocą modelu STDE nie tylko pozwala na 
określenie zachowania się związków na granicach faz, ale również umożliwia weryfikację danych uzyskanych metodami doświadczalnymi.

\section{AKTYWNOŚĆ POWIERZCHNIOWA DICHLORKÓW N,N-BIS(3,3'- DIMETYLOAMINOPROPYLO)ALKILAMIDÓW}

Dichlorki $\quad N, N$-bis(3,3'-dimetyloaminopropylo)alkilamidów $\quad \mathrm{Cn}(\mathrm{DAPACl})_{2}$ (struktura zamieszczona na Rys. 12) mają strukturę cząsteczkową podobną do soli $N, N$-bis(3,3'-trimetyloammoniopropylo)alkilamidów, jednakże grupami kationowymi są trzeciorzędowe aminy. N,N-bis(3,3'-dimetyloaminopropylo)alkilamidy $\mathrm{Cn}(\mathrm{DAPA})_{2} \mathrm{w}$ zależności od $\mathrm{pH}$ środowiska mogą występować $\mathrm{w}$ trzech formach [85] o różnym stopniu protonacji.

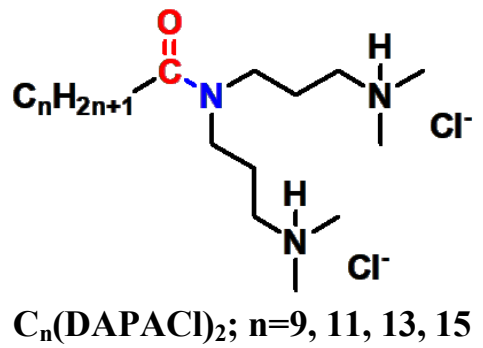

Rysunek 12. Struktura badanych kationowych surfaktantów dwufunkcyjnych - dichlorków amin Figure 12. Structure of studied cationic dicephalic surfactants - amine dichlorides

Zawartość poszczególnych form $(\mathrm{M}$ - forma niesprotonowana, $\mathrm{MH}$ monoprotonowana, $\mathrm{MH}_{2}$ - diprotonowana) w zależności od wartości pH roztworu wyznaczonej na podstawie miareczkowania konduktometrycznego $\mathrm{C}_{12}(\mathrm{DAPACl})_{2}$ przedstawiono na Rys. 13. Jednakże przeprowadzone pomiary $\mathrm{pH}$ roztworów poszczególnych dichlorków $\mathrm{C}_{\mathrm{n}}(\mathrm{DAPACl})_{2}$ dla stężeń odpowiadającym zakresowi występowania izoterm adsorpcji tych związków $\left(10^{-4}-10^{-1} \mathrm{M}\right)$ pokazały, że wartość pH nie przekracza 7, co oznacza, że w tych warunkach w roztworze obecna jest praktycznie tylko jedna, podwójnie protonowana, dwudodatnia forma $-\mathrm{MH}_{2}$.

Aktywność powierzchniowa związków typu soli amin, dichlorków $N, N$ bis(3,3'-dimetyloaminopropylo)alkilamidów $\mathrm{Cn}(\mathrm{DAPACl})_{2}$, została wyznaczona poprzez pomiary napięć powierzchniowych ich wodnych roztworów [85], a uzyskane izotermy przedstawiono na Rys. 14. W celach porównawczych naniesiono również izotermy napięcia powierzchniowego otrzymane uprzednio dla $\mathrm{C}_{12}(\mathrm{TAPABr})_{2} \mathrm{i} \mathrm{C}_{12}(\mathrm{TAPAMS})_{2}$. 


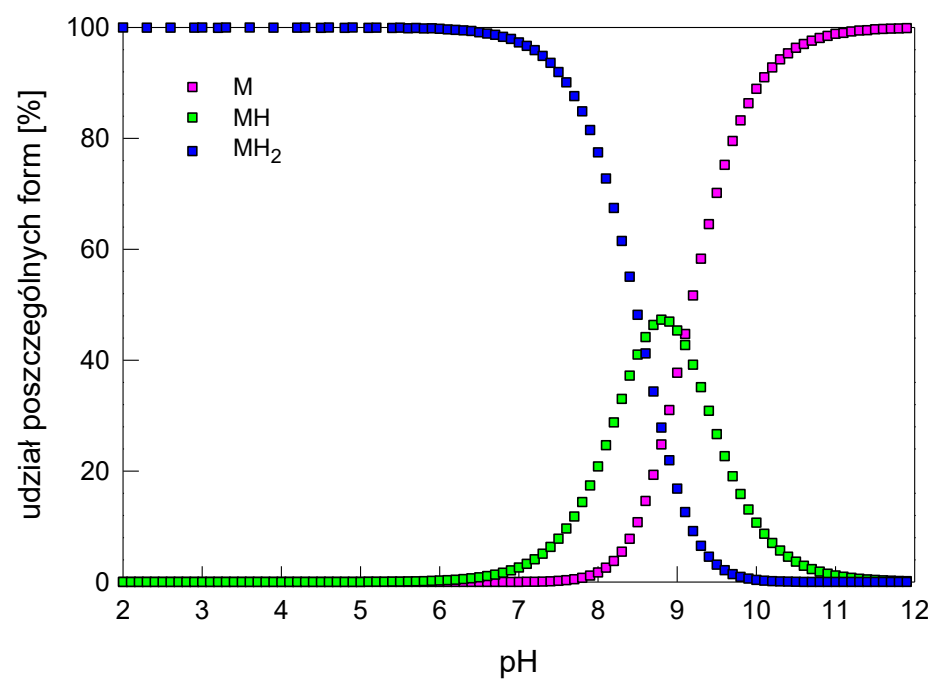

Rysunek 13. Zawartość procentowa poszczególnych form dichlorku N,N-bis(3dimetyloaminopropylo)dodekanamidu $\left(\mathrm{C}_{12}(\mathrm{DAPACl})_{2}\right)$ w zależności od $\mathrm{pH}$ [85]

Figure 13. Variation in the contribution of diprotonated $\left(\mathrm{MH}_{2}\right)$, monoprotonated $(\mathrm{MH})$ and deprotonated (M) forms of $\mathrm{N}, \mathrm{N}$-bis[3,3-(dimethylamine)propyl]dodecanamide dichloride with $\mathrm{pH}$ variation. Reprinted from [85] with permission from Elsevier

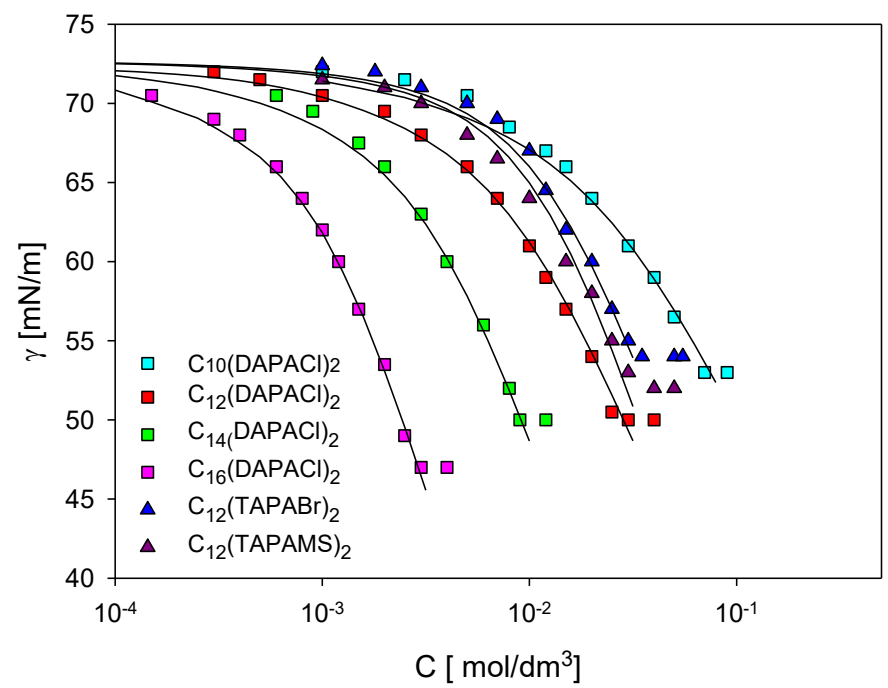

Rysunek 14. Zależność napięcia powierzchniowego $(\gamma)$ od stężenia dla dwufunkcyjnych dichlorków $\mathrm{Cn}(\mathrm{DAPACl})_{2} \quad(\mathrm{n}=10,12,14,16)$ oraz dla dibromku $\mathrm{C}_{12}(\mathrm{TAPABr})_{2}$ i dimetylosiarczanu $\mathrm{C}_{12}$ (TAPAMS $)_{2}$; liniami ciągłymi zaznaczono krzywe uzyskane na podstawie teoretycznego modelu adsorpcji surfaktantów jonowych (STDE) [85]

Figure 14. Surface tension $(\gamma)$ of dicephalic dichlorides $\mathrm{Cn}(\mathrm{DAPACl}) 2(\mathrm{n}=10,12,14,16)$ as function of surfactant concentration; lines represent fits of the theoretical model of ionic surfactant adsorption to experimental data (STDE model). Adapted from [85] with permission from Elsevier. 
Do opisu adsorpcji dichlorków na granicy faz ciecz/gaz zastosowano również rozszerzony model teoretyczny adsorpcji surfaktantów jonowych, STDE, a uzyskane wyniki dla parametrów najlepszego dopasowania zestawiono w Tabeli 2. Dla porównania przedstawiono również parametry uzyskane dla dodecylowych pochodnych soli bis-amoniowych, $\mathrm{C}_{12}(\mathrm{TAPABr})_{2}$ i $\mathrm{C}_{12}$ (TAPAMS $)_{2}$. Podobnie jak w przypadku bromków i metylosiarczanów przy obliczeniach teoretycznych procesu adsorpcji uwzględniono możliwość tworzenia się asocjatów jon surfaktantu - przeciwjon, których istnienie zostało potwierdzone poprzez pomiary stężenia wolnych jonów chlorkowych $\mathrm{Cl}^{-} \mathrm{w}$ roztworach dichlorków dwufunkcyjnych za pomocą jonoselektywnej elektrody chlorkowej, a uzyskane wyniki przedstawiono przykładowo dla $\mathrm{C}_{12}(\mathrm{DAPACl})_{2}$ na Rys. 15 [85].

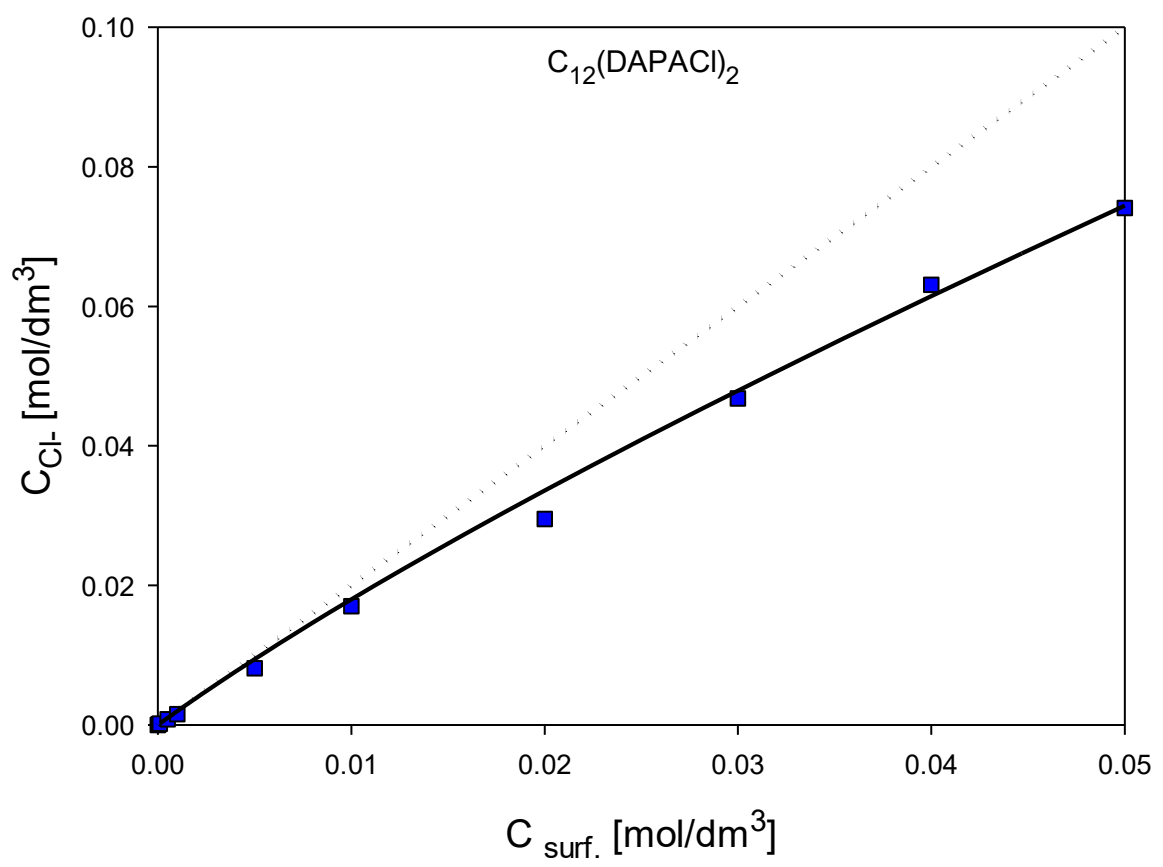

Rysunek 15. Stężenie jonów chlorkowych w roztworze $\mathrm{C}_{12}(\mathrm{DAPACl})_{2} \mathrm{w}$ funkcji stężenia surfaktantu; dane eksperymentalne zaznaczono punktami. Linia ciągła przedstawia krzywą teoretyczną wyznaczoną na podstawie równania 5.3, linia przerywana - hipotetyczne stężenie jonów chlorkowych przy pełnej dysocjacji surfaktantu [85]

Figure 15. Concentration of chloride ions in solution of $\mathrm{C} 12(\mathrm{DAPACl})_{2}$ as function of surfactant concentration. Symbols denote experimental data, the solid line represents the theoretical dependence (eq. 5.3), and the dotted line represents the hypothetical dependence in the absence of surfactant-counterion associates. Reprinted from [85] with permission from Elsevier 


\begin{tabular}{|c|c|c|c|c|c|c|c|c|}
\hline Związek & $\alpha_{S}\left(\mathrm{~mol} / \mathrm{dm}^{3}\right)$ & $\begin{array}{c}H_{S} \\
(\mathbf{k J} / \mathrm{mol})\end{array}$ & $\begin{array}{c}10^{6} \Gamma_{S} \\
\left(\mathrm{~mol} / \mathrm{cm}^{2}\right)\end{array}$ & $\begin{array}{c}A_{\min } \\
\left(\mathrm{nm}^{2}\right)\end{array}$ & $\begin{array}{c}\Delta G_{\text {ads }}^{0} \\
(\mathrm{~kJ} / \mathrm{mol})\end{array}$ & $\varepsilon$ & $\begin{array}{c}K \\
\left(\mathrm{dm}^{3} / \mathrm{mol}\right)\end{array}$ & $\begin{array}{c}\mathrm{cmc}^{b} \\
\left(\mathrm{~mol} / \mathbf{d m}^{3}\right)\end{array}$ \\
\hline $\mathrm{C}_{10}(\mathrm{DAPACl})_{2}$ & $3.3 \times 10^{-5}$ & 0.5 & 3.6 & 0.46 & -25.57 & 27 & 14 & $7.0 \times 10^{-2}$ \\
\hline $\mathrm{C}_{12}(\mathrm{DAPACl})_{2}$ & $3.1 \times 10^{-6}$ & 0.5 & 3.6 & 0.46 & -31.43 & 26 & 14 & $2.5 \times 10^{-2}$ \\
\hline $\mathrm{C}_{14}(\mathrm{DAPACl})_{2}$ & $2.5 \times 10^{-7}$ & 0.5 & 3.6 & 0.46 & -37.66 & 25 & 14 & $9.0 \times 10^{-3}$ \\
\hline $\mathrm{C}_{16}(\mathrm{DAPACl})_{2}$ & $1.0 \times 10^{-8}$ & 1.0 & 3.6 & 0.46 & -45.64 & 22.5 & 14 & $3.0 \times 10^{-3}$ \\
\hline
\end{tabular}

${ }^{a}$ Dalsze parametry: $\alpha_{\mathrm{Cl}}{ }^{-}=17000\left[\mathrm{~mol} / \mathrm{dm}^{3}\right], \delta=a_{\mathrm{Cl}}{ }^{-}=0.33[\mathrm{~nm}], \delta=a_{\mathrm{Br}}{ }^{-}=0.33[\mathrm{~nm}]$,

${ }^{b}$ Wartości cmc (krytycznego stężenia micelizacji) wyznaczono na podstawie izoterm przedstawionych na Rys. 14. 
Wskazują one, że stężenie jonów $\mathrm{Cl}^{-}$jest niższe niż przewidywane dla całkowitej dysocjacji, co świadczy o tworzeniu się asocjatów w układzie jon surfaktantu - przeciwjon. Pojawienie się dla stężenia powyżej $0.01 \mathrm{M}$ cząsteczek pojedynczo sprotonowanych wpływałoby na aktywność powierzchniową, natomiast nie powodowałoby spadku stężenia jonów chlorkowych. Świadczy to poprawności hipotezy odnośnie wyłącznego występowania podwójnie sprotonowanej formy surfaktantu. Wyniki doświadczalne bardzo dobrze opisuje krzywa teoretyczna, uzyskana na podstawie równania 5.3 przy wartości stałej asocjacji dla najlepszego dopasowania (patrz Tabela 2), zaznaczona na Rys. 15 linią ciągłą.

Badane dichlorki amin wykazują nieco wyższą aktywność powierzchniową w porównaniu z dwufunkcyjnymi dibromkami i dimetylosiarczanami amoniowymi $\mathrm{C}_{12}(\mathrm{TAPABr})_{2}$ i $\mathrm{C}_{12}$ (TAPAMS $)_{2}$, ale niższą niż ich liniowe odpowiedniki $\mathrm{C}_{12} \mathrm{TAPABr} \mathrm{i} \mathrm{C}_{12}$ TAPAMS. Różnica $\mathrm{w}$ aktywności powierzchniowej badanych związków jest dobrze widoczna $\mathrm{w}$ odniesieniu do wartości parametru $\alpha_{S}$ i standardowej energii adsorpcji $\Delta G_{\text {ads }}^{0}$ (Tabela 2). Na Rys. 16 została przedstawiona zależność standardowej energii adsorpcji, $\Delta G_{\text {ads, }}^{0}$ od liczby atomów węgla w łańcuchu alkilowym, $n_{\mathrm{C}}$, dla szeregu homologicznego dichlorków $N, N$ bis(3,3'-dimetyloaminopropylo)alkilamidów.

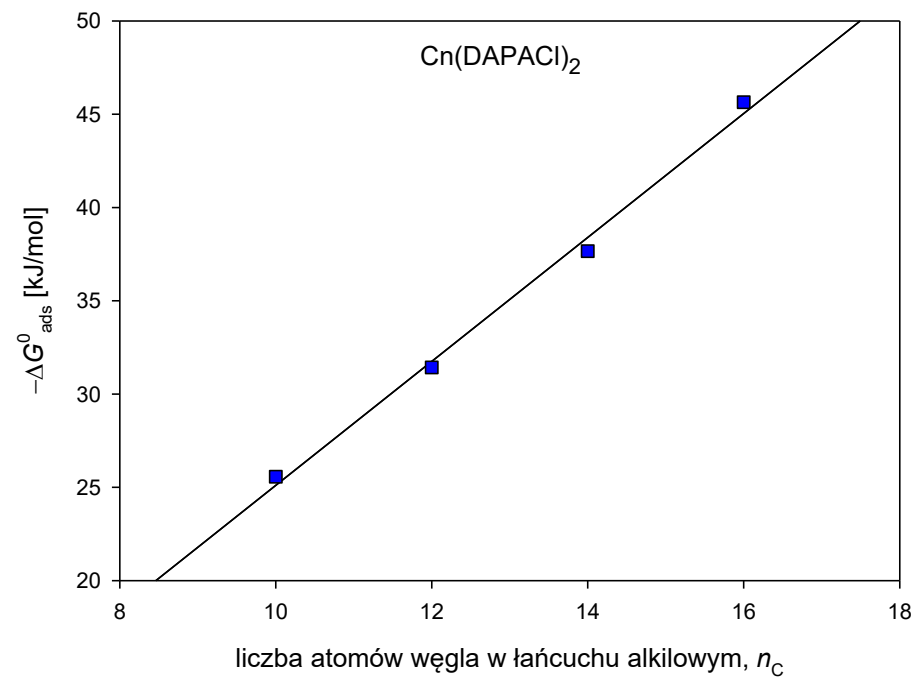

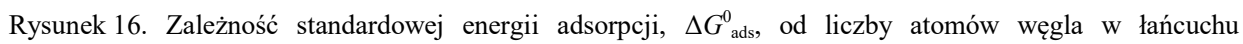
alkilowym, $n_{\mathrm{C}}$, dla $\mathrm{Cn}(\mathrm{DAPACl})_{2}[85]$

Figure 16. Dependence of the standard free energy of adsorption, $\Delta G_{\text {ads, }}^{0}$ on the number of carbon atoms, $\mathrm{n}_{\mathrm{C}}$, for homologues series of $\mathrm{Cn}(\mathrm{DAPACl})_{2}$. Reprinted from [85] with permission from Elsevier 
Liniowa zależność $\Delta G_{\text {ads }}^{0}$ od liczby atomów węgla w łańcuchu alkilowym jest zgodna z regułą Traubego dla szeregów homologicznych surfaktantów i dla badanych dichlorków $\mathrm{Cn}(\mathrm{DAPACl})_{2}$ może być przedstawiona następującym równaniem:

$$
\Delta G_{a d s}^{0}=-3.32 n_{C}+8.11
$$

w którym współczynnik korelacji $R^{2}=0.995$.

Wartość nadmiaru powierzchniowego, $\Gamma_{\mathrm{m}}$, wyznaczona z modelu STDE, dla dichlorków $\mathrm{C}_{\mathrm{n}}(\mathrm{DAPACl})_{2}$ jest nieco wyższa niż dla dwufunkcyjnych dibromków i dimetylosiarczanów. Można to uzasadnić mniejszym rozmiarem efektywnej średnicy grup hydrofilowych, ze względu na zastąpienie jednej grupy $\mathrm{CH}_{3}$ atomem wodoru w dichlorkach $\mathrm{Cn}(\mathrm{DAPACl})_{2}$. Prametr $H_{\mathrm{S}}$ dla wszystkich badanych związków dwufunkcyjnych o takiej samej liczbie atomów węgla w łańcuchu alkilowym jest stały, podobnie jak wartość stałej dielektrycznej w warstwie Sterna. Wartość parametru $\alpha_{c}$, wyrażającego zdolność przeciwjonu do penetracji warstwy Sterna, dla jonów chlorkowych jest znacznie wyższa niż dla jonów bromkowych czy metylosiarczanowych [46]. Oznacza to, że jony $\mathrm{Cl}^{-}$mają mniejsze powinowactwo do warstwy powierzchniowej i mniej efektywnie neutralizują ładunek podwójnej warstwy elektrycznej, niż jony $\mathrm{Br}^{-}$i $\mathrm{CH}_{3} \mathrm{OSO}_{3}^{-}$. Mimo to dichlorki są najbardziej aktywne powierzchniowo spośród badanych związków dwufunkcyjnych. Jest to związane wyższą tendencja do tworzenia asocjatów oraz $\mathrm{z}$ ich budową, a mianowicie mniejszym rozmiarem efektywnej średnicy grup hydrofilowych. Zastąpienie grupy $\mathrm{CH}_{3}$ atomem wodoru przy atomach azotu w cząsteczce dichlorku powoduje zwiększenie stopnia kompleksowania jonów chlorkowych. Przypuszczenie to potwierdza wyznaczona wartość stałej asocjacji. Najlepszy opis teoretyczny eksperymentalnych izoterm $\mathrm{C}_{\mathrm{n}}(\mathrm{DAPACl})_{2}$ został uzyskany dla $\mathrm{K}_{\mathrm{Cl}}=14 \mathrm{dm}^{3} / \mathrm{mol}$, wartości dwukrotnie większej niż dla dimetylosiarczanów (Tabela 2). Świadczy to o znacznie większym stopniu kompleksowania jonów chlorkowych przez jony surfaktantu i jest głównym czynnikiem prowadzącym do zwiększenia aktywności powierzchniowej dichlorków.

Zastosowany model kwazi-dwuwymiarowego elektrolitu do opisu procesu adsorpcji dichlorków $N, N$-bis(3,3'-dimetyloaminopropylo)alkilamidów daje możliwość skorelowania wyników otrzymanych metodami doświadczalnymi z obliczeniami teoretycznymi izoterm adsorpcji. Ponadto wyznaczone na podstawie modelu parametry pozwalają na przedstawienie bardziej dokładnego obrazu procesu adsorpcji. 


\section{UWAGI KOŃCOWE}

Surfaktanty dwufunkcyjne typu dicephalic wykazują aktywność powierzchniową na granicy faz ciecz/gaz niższą niż standardowe surfaktanty o tej samej liczbę atomów węgla w łańcuchu hydrofobowym. Wprowadzenie do cząsteczki dodatkowej „głowy” powoduje znaczny wzrost charakteru hydrofilowego, przejawiający się wyższymi wartościami krytycznego stężenia micelizacji $\mathrm{W}$ stosunku do surfaktantów o standardowej budowie. Analogicznie do klasycznych surfaktantów obserwuje się, charakterystyczny dla szeregów homologicznych, wzrost aktywności powierzchniowej wraz ze wzrostem długości łańcucha alkilowego. Oprócz długości łańcucha hydrofobowego wpływ na aktywność powierzchniową ma tworzenie par (asocjatów) surfaktant-przeciwjon. $Z$ zaprezentowanych kationowych surfaktantów dwufunkcyjnych najwyższą aktywność powierzchniową wykazują dichlorki amin. Związane jest to z nieco mniejszym rozmiarem ich hydrofilowych grup - trzeciorzędowych amin, gdyż zamiast grupy metylowej przy atomach azotu posiadają atom wodoru. W przypadku dibromków oraz dimetylosiarczanów amoniowych zaznacza się wyraźny wpływ przeciwjonu. Surfaktanty $\mathrm{z}$ jonami metylosiarczanowymi są bardziej aktywne powierzchniowo co wynika $\mathrm{z}$ większej zdolności tych jonów do penetracji warstwy Sterna.

Metody doświadczalne polegające na pomiarze napięć powierzchniowych/międzyfazowych dają ogólny obraz adsorpcji surfaktantów na granicy faz, natomiast szczegółowe dane dotyczące rozkładu jonów w warstwie dyfuzyjnej mogą być otrzymane na drodze rozważań teoretycznych z zastosowaniem odpowiedniego modelu adsorpcji. Zastosowanie do teoretycznego opisu procesu adsorpcji dwufunkcyjnych surfaktantów kationowych rozszerzonego modelu kwazidwuwymiarowego elektrolitu, uwzględniającego możliwość tworzenia się asocjatów w układzie wieloładunkowy jon surfaktantu - przeciwjon, pozwala na uzyskanie dobrej korelacji pomiędzy wynikami otrzymanymi na podstawie pomiarów a obliczeniami teoretycznymi.

\section{PODZIĘKOWANIA}

Praca powstała w ramach grantów: MNiSzW (Nr N N209 119537) oraz NCN OPUS 2017/25/B/ST4/02450 


\section{PIŚMIENNICTWO CYTOWANE}

[1] D.J.F. Taylor, R.K. Thomas, J. Penfold, Adv. Colloid Interface Sci. 2007, 132, 69.

[2] K. Holmberg, Langmuir, 2010, 26, 9276.

[3] A. Tehrani-Bagha, K. Holmberg, Curr. Opin. Colloid Interface Sci., 2007,12, 81.

[4] A. Sokołowski, A. Bieniecki, K.A. Wilk, B. Burczyk, Colloids Surf. A: Physicochem. Eng. Aspects, 1995, 98, 73.

[5] B. Burczyk, Biodegradable and Chemodegradable Nonionic Surfactants, [w:] Encyclopedia of Surface and Colloid Science, A. T. Hubbard, (red.) Marcel Dekker, Inc., New York - Basel 2002, s. $724-752$.

[6] B. Burczyk, Zielona Chemia: zadania, cele, przykłady i osiągnięcia; Wiadomości chemiczne 2002.

[7] E. Grabińska-Sota, Czwartorzędowe sole amoniowe-ocena oddziaływania na środowisko, Czwartorzędowe sole amoniowe i obszary ich zastosowań w gospodarce, Praca zbiorowa, red. R. Zieliński, Instytut Technologii Drewna, Poznań 2001.

[8] G. Para, A. Hamerska-Dudra, K.A. Wilk, P. Warszyński, Colloids Surf. A, 2011, 383, 67.

[9] S.K. Samanta, S. Bhattacharya, P.K. Maiti, J. Phys. Chem. B, 2009, 113, 13545.

[10] N. Gao, J. Dong, G. Zhang, X. Zhou, J. Eastoe, J. Mutch, R.K. Heenan, J. Colloid Interface Sci. 2007, 314, 707.

[11] K.Z. Roszak, S.L. Torcivia, K.M. Hamill, A.R. Hill, K.R. Radloff, D.M. Crizer, A.M. Middleton, K.L. Caran, J. Colloid Interface Sci., 2009, 331, 560.

[12] S. Bhattacharya, S.K. Samanta, J. Phys. Chem. Lett., 2011, $2,914$.

[13] J. Haldar, V.K. Aswal, P.S. Goyal, S. Bhattacharya, J. Colloid Interface Sci., 2005, 282, 156.

[14] Ł. Lamch, K. Witek, E. Jarek, E. Obłąk, P. Warszyński, K.A. Wilk, J. Colloid Interface Sci., 2020, 558, 220.

[15] A.J. Jackson, P.X. Li, C.C. Dong, R.K. Thomas, J. Penfold, Langmuir, 2009, 25, 3957.

[16] G. Bai, J. Wang, H. Yan, Z. Li, R.K. Thomas, J. Phys. Chem. B, 2001, 105, 3105.

[17] J. Haldar, P. Kondaiah, S.J. Bhattacharya, Med. Chem., 2005, 48, 3823.

[18] A. Meister, A. Blume, Curr. Opin. Colloid Interface Sci., 2007, 12, 138.

[19] J. Węgrzyńska, G. Para, J. Chlebicki, P. Warszyński, K.A. Wilk, Langmuir, 2008, 24, 3171.

[20] R. Zana, J. Xia, Gemini Surfactants: Synthesis, Interfacial and Solution-Phase Behaviour, and Applications; Marcel Dekker: New York, 2004.

[21] K. Din, M.S. Sheikh, A.A. Dar, J. Phys. Chem. B, 2010, 114, 6023.

[22] T. Yoshimura, A. Ohno, K. Esumi, Langmuir, 2006, 22, 4643.

[23] S. Langsrud, M. Sidhu, E. Heir, A. Holck, Int. Biodeter. Biodegr., 2003, 51, 283.

[24] J. Moran, M. Addy, R. Jackson, R. Nowcombe, J. Clin, Pesidontol. 2000, $27,37$.

[25] A. Skrzypczak, J. Błaszczak, Aktywność powierzchniowa czwartorzędowych dichlorków bisamoniowych pochodnych 1-alkiloimidazoli, Instytut Technologii Drewna, 107, Poznań 2005.

[26] O. Farago, K. Ewert, A. Ahmad, H.M. Evans, N. Gronbech-Jensen, C.R. Safinya, Biophys. J. 2008, 95, 836 .

[27] A. Piecuch, Ł. Lamch, E. Paluch, E. Obłąk, K.A. Wilk, J. Appl. Microbiol., 2016, 121, 682.

[28] E. Paluch, A. Piecuch, E. Obłąk, Ł. Lamch, K.A. Wilk, Colloids Surf. B, 2018, 164, 34.

[29] S. Bhattacharya, S. De, Chem. Eur. J., 1999, 5, 2335.

[30] K.K. Ewert, H.M. Evans, A. Zidovska, N.F. Bouxsein, A. Ahmad, C.R.A. Safinya, J. Am. Chem. Soc., 2006, 128, 3998.

[31] K.N. Jayaprakash, J. Lu, B. Fraser-Reid, Angew. Chem., Int. Ed., 2005, 44, 5894.

[32] M. Antonietti, Curr. Opin. Colloid Interface Sci., 2001, 6, 244.

[33] K. Holmberg, Curr. Opin. Colloid Interface Sci., 2003, 8, 187.

[34] J. Haldar, V.K. Aswal, P.S. Goyal, S. Bhattacharya, J. Phys. Chem. B, 2001, 105, 12803. 
[35] D.M. Wawrzyńczyk, U.J. Bazylińska, Ł. Lamch, J. Kulbacka, A.A. Szewczyk, A. Bednarkiewicz, K.A. Wilk, M. Samoć, ChemSusChem, 2019, 12, 706.

[36] R.S. Dias, B. Lindman, DNA Interactions with Polymers And Surfactants. John Wiley \& Sons; 2008 ,

[37] J. Chlebicki, J. Węgrzyńska, K.A. Wilk, J. Colloid Interface Sci., 2008, 323, 372.

[38] W. Wang, W. Lu, L. Jiang, J. Phys. Chem. B, 2008, 112, 1409.

[39] X. Yan, S. Han, W. Hou, X. Yu X, C. Zeng, X. Zhao, H. Che, Colloids Surf. A, 2007, 303, 219.

[40] W. Zieliński, K.A. Wilk, G. Para, E. Jarek, K. Ciszewski, J. Palus, P. Warszyński, Colloids Surf. A, 2015, 480, 63 .

[41] S. Mishra, V.K. Tyagi, J. Oleo Sci,. 2007, 56, 269.

[42] J. Cross, E.J. Singer, Cationic surfactants, analytical and biological evaluation; Surfactant Science Series, Vol. 53; Marcel Dekker Inc.: New York, 1994.

[43] D.N. Rubingh, P.M. Holland, Cationic Surfactants: Physical Chemistry; Marcel Dekker: New York, 1991.

[44] D. Myers, Surfactants Science and Technology, 3 ed.; John Wiley \& Sons, Inc.: Hoboken, NJ, 2006.

[45] K. Cho, K. Na, J. Kim, O. Terasaki, R. Ryoo, Chem. Mater., 2012, 24, 2733, doi: $10.1021 / \mathrm{cm} 300841 \mathrm{v}$.

[46] G. Para, E. Jarek, P. Warszyński, Adv. Colloid Interface Sci., 2006, 122, 39 .

[47] L. Pérez, A. Pinazo, M. R. Infante, R. Pons, J. Phys. Chem. B, 2007, 111, 11379.

[48] K. Dopierała, J. Łuczyński, K. Prochaska, Adv. Colloid Interface Sci., 2009, 151, 49.

[49] G. Para, P. Warszyński, Colloids Surf. A, 2007, 300, 346.

[50] A. Adamson, A.P. Gast, Physical Chemistry of Surfaces, 6th Edition, Wiley \& Sons, Inc., New York, 1997.

[51] J.W. Gibbs, The Collected Works of J. Willard Gibbs, Vol. 1, Yale University Press, New Haven, 1957 .

[52] R. Zana, Adv. Colloid Interface Sci., 2002, 97, 205.

[53] R. Miller, G. Kretzschmar, Colloid Polymer Sci., 1980, 258, 85.

[54] A.F.G. Ward, L. Tordai, J. Chem. Phys., 1949, 14, 453.

[55] J.F. Baret, J. Colloid Interface Sci., 1969, 30, 1.

[56] I. Langmuir, J. Am. Chem. Soc., 1918, 40, 1361.

[57] A. Frumkin, Z. Phys. Chem., 1925, 116, 466.

[58] E. Helfand, H.L. Frisch, J.L. Lebowitz, J. Chem. Phys., 1961, 34, 1037.

[59] I.B. Ivanov, K.P. Ananthapadmanabhan, A. Lips, Adv. Colloid Interface Sci., 2006, 123-126, 189, doi: 10.1016/j.cis.2006.05.020.

[60] O. Stern, Z. Electrochem., 1924, 30, 508.

[61] J.T. Davies, E.K. Rideal, Interfacial Phenomena. New York: Academic Press, 1963.

[62] R.P. Borwankar, D.T. Wasan, Chem. Eng. Sci., 1986, 1, 199.

[63] R.P. Borwankar, D.T. Wasan, Chem. Eng. Sci., 1988, 43, 1323.

[64] V.V. Kalinin, C.J. Radke, Colloids Surf A, 1996, 114, 337.

[65] D.C. Grahame, Chem. Rev., 1947, 41, 441.

[66] P.A. Kralchevsky, K.D. Danov, G. Broze, A. Mehreteab, Langmuir, 1999, 15, 2351.

[67] K.D. Danov, P.M. Vlahovska, P.A. Kralchevsky, G. Broze, A. Mehreteab, Colloid Surf., 1999, 156, 389 .

[68] V.B. Fainerman, E.H. Lucassen-Reynders, R. Miller, Colloids Surf., A 1998, 143, 141.

[69] V.B. Fainerman, E.H. Lucassen-Reynders, Adv. Colloid Interface Sci., 2002, 96, 295.

[70] P. Warszyński, W. Barzyk, K. Lunkenheimer, H. Fruhner, J. Phys. Chem. B., 1998, 102, 10948.

[71] P. Warszyński, K. Lunkenheimer, G. Czichocki, Langmuir, 2002, 18, 2506.

[72] G. Para, E. Jarek, P. Warszyński, Z. Adamczyk, Colloids Surf A, 2003, 222, 213. 
[73] G. Para, E. Jarek, P. Warszyński, Colloids and Surfaces A, 2005, 261, 65.

[74] P. Warszyński, D.K. Wantke, H. Fruhner, Colloids Surf A, 2001, 189, 29.

[75] E. Jarek, P. Wydro, P. Warszyński, M. Paluch, J. Colloids Interface Sci., 2006, 293, 194.

[76] E. Jarek, T. Jasiński, W. Barzyk, P. Warszyński, Colloids Surfaces A, 2010, 354(1-3), 188.

[77] N.A.J.M. Sommerdijk, T.L. Hoeks, K.J. Booy, M.C. Feiters, R.J.M. Nolte, Zwanenburg B. Chem. Commun., 1998, 1998, 743.

[78] R. Frąckowiak, K.A. Wilk, A. Piasecki, Patent. Polska, nr 211857. Bis-amoniowe sole alifatycznych amidów 3,3'-iminobis(N,N-dimetylopropyloaminy) i sposób ich wytwarzania : Int. Cl. C07C 237/00, C07C 231/00. Zgłosz. nr 388525 z 13.07.2009. Opubl. 31.07.2012. 4 s.

[79] G. Archontis, E. Leontidis, G. Andreou, J. Phys. Chem. B, 2005, 109, 17957.

[80] P. Jungwirth, D. J. Tobias D, J. Phys. Chem. B, 2002, 106, 6361.

[81] L. Vrbka, M. Mucha, B. Minofar, P. Jungwirth, E.C. Brown, D.J. Tobias, Curr. Opin. Colloid Interface Sci., 2004, 9, 67.

[82] G. Para, A. Hamerska-Dudra, K.A. Wilk, P. Warszyński, Colloids Surf. A, 2010, 365, 215.

[83] K. Kalyanasundaram, J.K. Thomas, J. Am. Chem. Soc., 1977, 99, 2039.

[84] R. Frąckowiak, G. Para, P. Warszyński, K.A. Wilk, Colloids and Surfaces A: Physicochem. Eng. Aspects, 2012, 413, 108.

Praca wpłynęła do Redakcji 1 kwietnia 2021 r. 
